\title{
Synthesis and structural insights into the binding mode of the albomycin $\delta 1$ core and its analogues in complex with their target aminoacyl-tRNA synthetase
}

Bharat Gadakh ${ }^{1}$, Gaston Vondenhoff ${ }^{1,3}$, Luping Pang ${ }^{1,2}$, Manesh Nautiyal ${ }^{1}$, Steff De Graef ${ }^{2,4}$, Sergei V. Strelkov ${ }^{2}$, Stephen D. Weeks ${ }^{2,4}$ and Arthur Van Aerschot ${ }^{1, *}$

${ }^{1}$ Medicinal Chemistry, Rega Institute for Medical Research, KU Leuven, Herestraat 49 box 1041, B-3000 Leuven, Belgium

2 Biocrystallography, Department of Pharmaceutical and Pharmacological Sciences, KU Leuven, Herestraat 49 box 822, B-3000 Leuven, Belgium

${ }^{3}$ Present address: Roche Diagnostics GmbH, DXRESA7G6164, Staffelseestrasse 2-8, 81477 Munich, Germany

${ }^{4}$ Present address: OrthogonX, Gaston Geenslaan 1, 3001 Leuven, Belgium E-mail: sweeks@orthogontherapeutics.com

* To whom correspondence should be addressed. Tel: +32 163726 24; Fax: +32 163373 40;

Email: arthur.vanaerschot@,kuleuven.be 


\begin{abstract}
Despite of proven efficacy and well tolerability, albomycin is not used clinically due to scarcity of material. Several attempts have been made to increase the production of albomycin by chemical or biochemical methods. In the current study, we have synthesized the active moiety of albomycin $\delta 1$ and investigated its binding mode to its molecular target seryl-trna synthetase (SerRS). In addition, isoleucyl and aspartyl congeners were prepared to investigate whether the albomycin scaffold can be extrapolated to target other aminoacyl-tRNA synthetases (aaRSs) from both class I and class II aaRSs, respectively. The synthesized analogues were evaluated for their ability to inhibit the corresponding aaRSs by an in vitro aminoacylation experiment using purified enzymes. It was observed that the diastereomer having the $5^{\prime} S, 6^{\prime} R$-configuration (nucleoside numbering) as observed in the crystal structure, exhibits excellent inhibitory activity in contrast to poor activity of its companion $5^{\prime} R, 6^{\prime} S$-diasteromer obtained as byproduct during synthesis. Moreover, the albomycin core scaffold seems well tolerated for class II aaRSs inhibition compared with class I aaRSs. To understand this bias, we studied X-ray crystal structures of SerRS in complex with the albomycin $\delta 1$ core structure 14a, and AspRS in complex with compound 16a. Structural analysis clearly showed that diastereomer selectivity is attributed to the steric restraints of the active site of SerRS and AspRS.
\end{abstract}

\title{
Graphical abstract
}
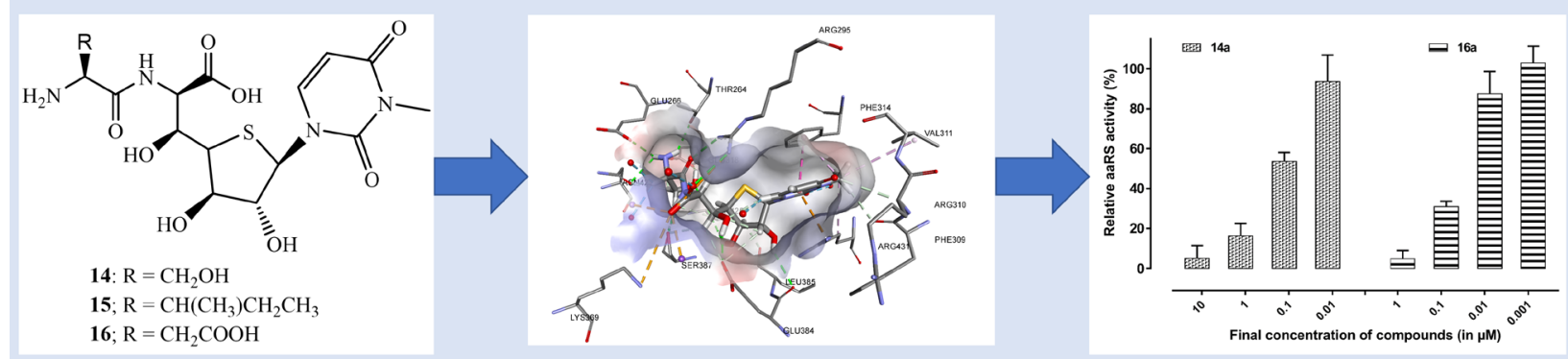


\section{Keywords}

Albomycin, albomycin analogues, aminoacyl-tRNA synthetase inhibitors, serine-tRNA synthetase, X-ray crystallography, structural analysis, natural product synthesis.

\section{Highlights}

- Total synthesis of albomycin core scaffold targeting serRS was accomplished

- Additional aspartyl- and isoleucyl-congeners were elaborated

- Aspartyl analogue strongly inhibiting aspRS in contrast to isoleucyl analogue

- 3D-Structural analysis of the albomycin core scaffold-serRS interactions

- Co-crystal structure of the aspartyl analogue and its aspRS target 


\section{Introduction}

Albomycin is a natural antibiotic produced by Streptomyces strain ATCC 700974 as a mixture of closely related compounds (Fig 1, 1a-c) [1, 2]. It is also known as grisein [3] and was discovered by Gause and Brazhnikovain 1951 from an Actinomyces subtropicus [4] culture, while its correct structure was uncovered by Benz et al. in 1982 [5-7]. Albomycin is a Trojan-horse antibiotic belonging to the sideromycins. Structurally, it consists of the active moiety linked to a siderophore, an iron chelator essential for cellular uptake. The active moiety (shown in red) comprises of a thioxylonucleoside linked to L-serine via an amide linkage mimicking the seryladenylate intermediate and thus acts as a seryl-tRNA synthetase (SerRS) inhibitor. The siderophore part consists of an L-ornithine tripeptide-based trihydroxamate (shown in blue) and is attached to the active moiety via a cleavable amide bond [8]. Albomycins are classified as $\delta 1, \delta 2$ and $\varepsilon$ based on their substituent at the C4-position of the pyrimidine base. The siderophore part is responsible for uptake of the active part due to its ability to complex iron and being recognized by the bacterial iron uptake receptor $[8,9]$.

Albomycin is highly effective against many gram-positive and gram-negative bacteria with MIC for the isolated compound of $10 \mathrm{ng} / \mathrm{mL}$ against Streptococcus pneumoniae and $5 \mathrm{ng} / \mathrm{mL}$ against $E$. coli [8]. Shortly after its discovery, albomycin has been successfully used in children to treat infections caused by pathogenic cocci. It proved to be safe and effective to treat septic complications of dysentery, measles and meningitis caused by penicillin-resistant pneumococci [4]. More recently, Pramanik et al. re-examined the activity spectrum and in vivo efficacy of albomycin in a mouse model. Herein, it was found that albomycin is effective to treat bacterial infections caused by gram-positive and gram-negative pathogens. In mice, the maximum dose tested was 50 million units $/ \mathrm{Kg}$ by either intravenous or subcutaneous administration but without any sign of toxicity $[4,10]$ (with one unit of albomycin inhibiting the growth of staphylococci in $1 \mathrm{ml}$. of nutritive agar, being approximately equal to 1/50 unit of penicillin [4]). Despite of proven efficacy and safety of albomycin, its use as a potential antibiotic was abandoned due to scarcity of the material. Therefore, ever since its discovery, efforts have been made to improve the yield of albomycin production and to develop it into a commercial drug [11, 12]. Indeed, Benz et al. reported the synthesis of albomycin $\delta 1$ analogue replacing thioxylofuranose with xylofuranose. However, the newly synthesized analogue was reported to be devoid of antibacterial activity [5]. In 1985, Fiedler et al. optimized the fermentation conditions to increase the yield of albomycin 
from $1 \mathrm{mg} / \mathrm{L}$ to $25 \mathrm{mg} / \mathrm{L}$ [13]. However, this amount is not sufficient for industrial application. Moreover, downstream processing proved cumbersome to obtain pure albomycin. In 1991, Holzapfel et al. claimed to have synthesized the thionucleoside moiety of albomycin $\delta 1$. However, synthetic details and analytical data were not disclosed [14].

After identification of the albomycin biosynthesis gene cluster, it was envisioned that implementation of bioengineering strategies could lead to production of intermediates which can be used to produce albomycin in sufficient amounts [12]. However, no follow-up has been disclosed. In parallel with efforts to improve the albomycin production along with better purification strategies, we focused on a total synthetic strategy for albomycin production. Our intent therefore was to follow a convergent approach where the active moiety and siderophore part would be synthesized separately and will be coupled at a later stage. We further hypothesized that we potentially can target various aminoacyl-tRNA synthetases (aaRSs) by substituting L-serine with variant amino acids. Recently, He and coworkers focused on an analogous strategy and successfully demonstrated total synthesis of albomycin and its base modified congeners [15]. They confirmed the antibacterial potential and proved albomycin $\delta 2$ exhibited potent antimicrobial activities against clinical $S$. pneumoniae and $S$. aureus isolates including MRSA. These results prompted us to share the details of our chemical efforts in elaborating the albomycin $\delta 1$ core as well as its functionalization with aspartic acid and isoleucine, thus successfully targeting other members of the aaRS family. We further disclose biochemical and structural details of our enzymatic interaction studies, allowing further improvement of the core structure binding mode via modeling.

\section{Chemistry}

\subsection{Retrosynthetic analysis of albomycin}

As shown in Figure 1, retrosynthetic analysis indicates the active moiety (A) and the siderophore part (B) can be synthesized separately and can be coupled by a conventional peptide coupling strategy. The siderophore part can be synthesized from L-ornithine tripeptide (F) following indirect oxidation method reported by Miller [16]. The tripeptide (F) itself, is synthesized from L-ornithine (G) following conventional peptide chemistry. In parallel, the active moiety can be synthesized from 4'-thio-xylonucleoside $(\mathbf{C}$, alcohol) by chain elongation reaction of the 
nucleoside aldehyde and appropriately protected glycine (D) [17], while further elongation is accomplished via reaction with appropriately protected active ester of L-serine (E) or another amino acid. The albomycin core structure $(\mathbf{X})$ depicts the scaffold before attaching serine for targeting SerRS, and can be used to couple other amino acids broadening the potential scope for inhibiting protein synthesis with a series of congeners.

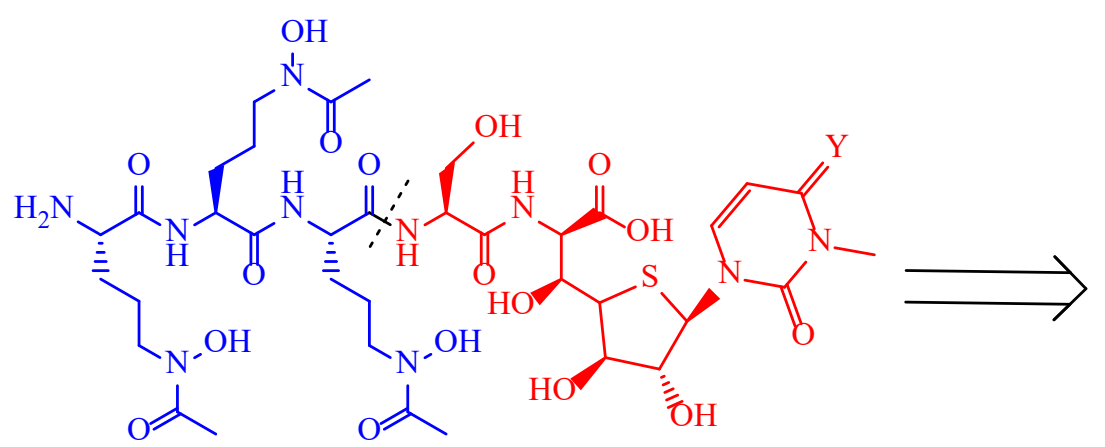

Albomycin $\delta 1$ (1a); Y = O

Albomycin $\delta 2$ (1) $) ; \mathrm{Y}=\mathrm{NCONH}_{2}$

Albomycin ${ }^{\varepsilon}$ 1c); $\mathrm{Y}=\mathrm{NH}$

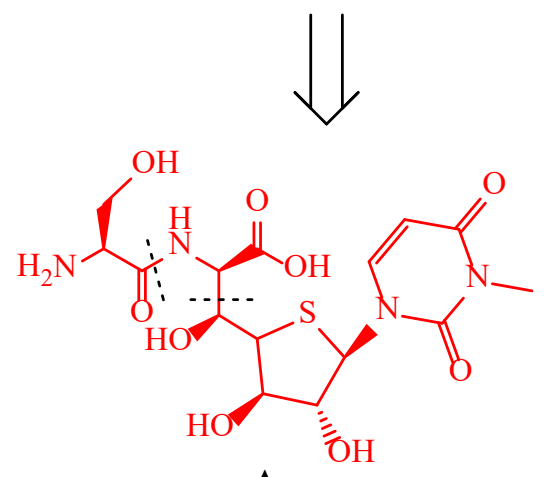

A

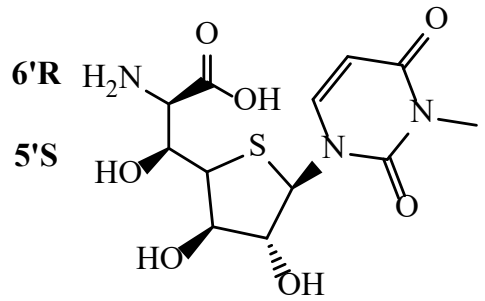

Core structure<smiles>CC(=O)N(O)CCC[C@H](N)C(=O)N[C@@H](CCCN(O)C(C)=O)C(=O)N[C@@H](CCCN(O)C(C)=O)C(=O)O</smiles>

B<smiles>CC(C)CCCC(=O)O</smiles>

$\mathbf{E}$

D

C<smiles>C=C(N[C@@H](CCCN)C(=O)O)[C@H](CCCN)NC(=O)[C@H](N)CCCN</smiles>

Fig. 1. Structures of the natural albomycin congeners and retrosynthetic analysis of albomycin $\delta 1$. The various starting building blocks are indicated with in the middle the key core structure $\mathbf{X}$ enabling synthesis of albomycin analogues via coupling with amino acids at its 6'-amino terminus. 
We previously already followed the outlined strategy for the siderophore part and used this particular uptake module in our efforts for improvement of uptake of some aminoacyl sulfamoyl adenosine derivatives (aaSAs), which displayed strong enzyme inhibitory activity in cell extracts [18]. Here, in an effort to understand the binding mode of albomycin in the active site of SerRS, we focused on synthesis of the active core of albomycin $\delta 1$, which is outlined in Scheme 1 . Larabinose upon treatment with in situ generated $\mathrm{HCl}$ in methanol at $55^{\circ} \mathrm{C}$ yielded methyl arabinoside (3) according to literature procedure $[19,20]$. Next, the 3 - and 4-hydroxyl groups were selectively activated via their dibutyltin acetal followed by treatment with tosyl chloride in presence of DMAP as a base to yield a mixture of regioisomers (4 and 5) in 1:2 ratio [21, 22]. The required 4-O-tosyl derivative (5) was taken further for synthesis and converted into 6 using $\mathrm{BzCl}$ in pyridine in presence of catalytic DMAP $[23,24]$. The L-arabinoside was further converted to its 4-thio-epimer, thio-D-xylopyranoside, by nucleophilic displacement of 4-O-tosyl using potassium thioacetate at $80^{\circ} \mathrm{C}$ in DMF as a solvent with little modification to literature procedure $[25,26]$. Acidolysis of methyl glycoside followed by ring contraction (ring opening and closing) and acetylation was achieved by treatment of 7 with conc. $\mathrm{H}_{2} \mathrm{SO}_{4}$ in acetic acid and acetic anhydride as solvent to yield 4-thio-D-xylofuranose 8 as a mixture of $\alpha / \beta$ anomers. [25, 27] The thioxylofuranose derivative $\mathbf{8}$ upon reaction with uracil under silyl-Hilbert-Johnson glycosylation conditions followed by methylation using MeI yielded compound 10 [28]. Further, selective removal of 5'-O-acetyl was accomplished by in situ generated $\mathrm{HCl}$ using acetyl chloride in a mixture of methanol and DCM to yield appropriately protected thio-xylonucleoside 11. 

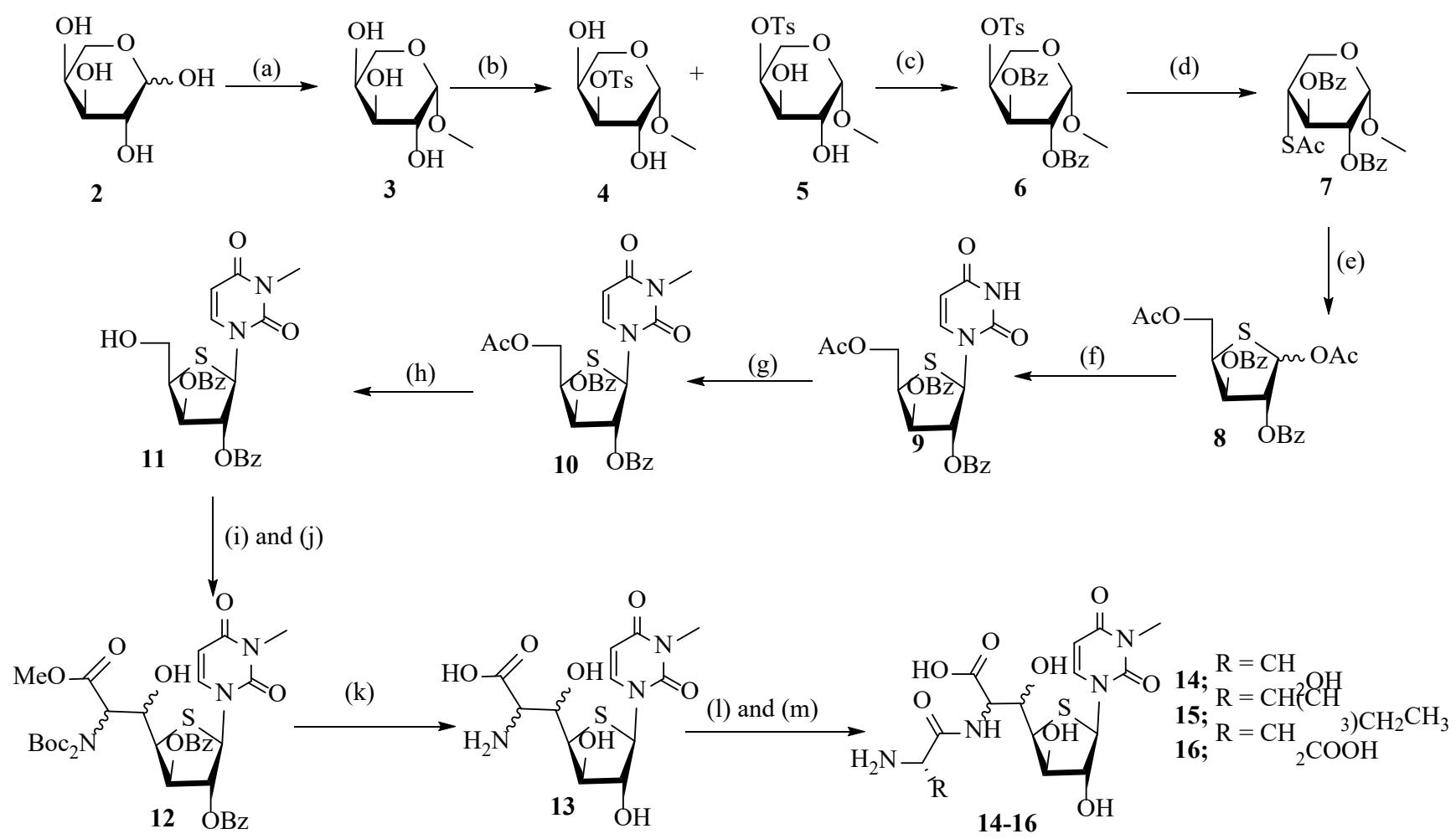

Scheme 1. Total synthesis of albomycin $\delta 1$ core structure (14) and its isoleucine (15) and aspartate (16) congeners as a mixture of the $5^{\prime} S, 6^{\prime} R$ and $5^{\prime} R, 6^{\prime} S$ isomers. Reagents and conditions: (a) $\mathrm{AcCl}, \mathrm{MeOH}, 0{ }^{\circ} \mathrm{C}$ to $55{ }^{\circ} \mathrm{C}, 4 \mathrm{~h} ; 74 \%$; (b) i. $\mathrm{Bu} 2 \mathrm{SnO}$, dry $\mathrm{MeOH}$, reflux overnight; ii. DMAP, TsCl, 1,4-dioxane, rt, 24 h; 62\%; (c) DMAP, BzCl, pyridine, 24 h, 92\%; (d) KSAc, DMF, $80^{\circ} \mathrm{C}$, $6 \mathrm{~h}, 51 \%$; (e) Conc. $\mathrm{H}_{2} \mathrm{SO}_{4}$, acetic acid, acetic anhydride, $-10^{\circ} \mathrm{C}$ to $4^{\circ} \mathrm{C}$, overnight, $75 \%$; (f) BSA, uracil, $\mathrm{SnCl}_{4}, \mathrm{ACN}, 40^{\circ} \mathrm{C}$, overnight, $72 \%$; (g) $\mathrm{K}_{2} \mathrm{CO}_{3}$, MeI, acetone: $\mathrm{DMF}, 70^{\circ} \mathrm{C}$, overnight, $71 \%$; (h) AcCl, DCM: $\mathrm{MeOH}$, rt, overnight; 89\%; (i) Dess-Martin, DCM, $0^{\circ} \mathrm{C}, 3$ h; (j) i. nBuLi, DIPA, THF, $-78^{\circ} \mathrm{C}, 2 \mathrm{~h}$, ii. $\mathrm{Boc}_{2} \mathrm{GlyOMe}$, THF, $-78^{\circ} \mathrm{C}, 1 \mathrm{~h}, 43 \%$; (k) i. $\mathrm{NaOH}, 1,4$-dioxane and water, $0^{\circ} \mathrm{C}$ to rt, 2 h; ii. TFA; (1) Boc-aa-OSu, $\mathrm{NaHCO}_{3}$, THF: water, rt, overnight; (m) TFA/water (5:2)

The chain elongation reaction is the most challenging step for albomycin total synthesis in view of its low yield, while obtaining the required stereoselectivity provides the second hurdle. Numerous attempts were undertaken to optimize the two-step elongation reaction (oxidation and C-C coupling). Several oxidizing agents such as IBX, Dess-Martin, PCC or Swern oxidation were investigated to yield the intermediate aldehyde in good yield and purity. The Dess-Martin periodinane afforded us the best results. Here, $\mathrm{Boc}_{2} \mathrm{GlyOMe}$ was used as $\mathrm{C}$-nucleophile in presence of LDA to yield elongated product 12. The second step was optimized in changing the equivalents of $\mathrm{Boc}_{2} \mathrm{GlyOMe}$, LDA, temperature, time and quenching reagent. Finally, the elongated product 12 was obtained as a mixture of two diastereomers ( 1:1 ratio) in up to $43 \%$ yield (2-step reaction). 
Having compound 12 (as a mixture of two diastereomers) in hand, separation of diastereomers was attempted using various HPLC conditions but without success. We therefore decided to separate the diastereomers at a later stage of synthesis.

Acetylation of 5'-OH was attempted with the aim to be able to remove all esters at a later stage in a single step. However, protection of 5'-hydroxyl moiety even at increased temperature proved unsuccessful due to steric hindrance. Leaving the alcohol unprotected, the Boc groups of 12 were removed by 30\% TFA in DCM at room temperature. However, following amino acid coupling, we observed that the benzoyl group had migrated from 3'- to 5'-hydroxyl leading to elimination reaction with the double bond residing between $\mathrm{C}^{\prime}-\mathrm{C} 6$ '. We therefore decided to remove the benzoyl protecting groups before coupling. Unfortunately, deprotection of Boc followed by removal of the benzoyl esters leads to undesired migration to the 6-amino position to yield benzamide. Following optimization, one-pot deprotection of benzoyl groups and methyl ester, followed by removal of Boc yielded most optimal results. However, purification of the obtained nucleoside derivative 13 proved cumbersome. Notably, He and co-workers published total synthesis of albomycins, which was enabled using the less known 2,3-butanedione for protection of sugar hydroxyl moieties and proved more straightforward. We therefore believe the choice for the right protecting groups is the key for successful albomycin total synthesis [15].

Having nucleoside $\mathbf{1 3}$ in hand, we evaluated several reaction conditions to obtain selective aminoacylation of the 7-amine position. For example, using a transient protection strategy protecting carboxyl and hydroxyl moieties using TMSCl [29], we found the $N$-hydroxy succinimide ester was too weak to effect aminoacylation, whereas aminoacyl chloride is too reactive and leads to partial racemization during the coupling reaction. Finally, using the $N$ hydroxysuccinimide ester in the presence of sodium bicarbonate as the base in a mixture of THF and water, provided us the desired $\mathrm{N}$-aminoacylated product. Here, $\mathrm{NaHCO}_{3}$ is forming a salt with the carboxylic acid and thus acts as a transient protection, while being too weak to effect aminoacylation of the hydroxyl moiety. Using this methodology, we coupled three amino acids, either serine, isoleucine or aspartic acid, to thionucleoside 13. The coupled products upon acidolysis of Boc and side chain protecting groups (TBDMS in case of serine and ${ }^{t} \mathrm{Bu}$ in case of aspartic acid) yielded the final products (14-16) as a mixture of two diastereomers. Reverse phase HPLC using Adamas C18-X-bond columns with ACN and water containing $50 \mathrm{mM}$ TEAB as eluens, provided separation of the serine and aspartic acid isomers. Isoleucine and aspartic acid 
were coupled to the core albomycin scaffold as representative examples for obtaining potential inhibitors for class I and other class II aaRSs, respectively.

\section{Enzyme inhibitory activity of the synthesized compounds}

Without any reference compound in hand, the identity of the purified compounds and presence of the correct stereoisomer could not be determined based on elution profile, but was assigned upon evaluation of their enzyme inhibitory activity. Hereto, the isolated derivatives were tested by an in vitro aminoacylation reaction using purified aaRSs and measuring the transfer of radiolabelled amino acid to tRNA [30]. We later confirmed the correct stereochemistry via X-ray analysis.

Aminoacylation reactions were carried out with a total tRNA pool and the appropriate purified enzymes from E. coli. This obviously is an indirect method of assessing the right stereoisomer, but we expected to see considerable differences in biological activity, with at least strong inhibitory activity for the serine isomer corresponding to the albomycin warhead structure. Indeed, one isomer of the serine congener ser-Xa (14a, $\left.5^{\prime} S, 6^{\prime} R\right)$, showed around $50 \%$ enzyme inhibition at $0.1 \mu \mathrm{M}$ concentration, and $80 \%$ at $1 \mu \mathrm{M}$ (Figure 2) while the other isomer ser-Xb $\left(14 b, 5\right.$ 'R, $\left.6^{\prime} S\right)$ only displayed about $25 \%$ inhibition at $10 \mu \mathrm{M}$, a more than 100 -fold decrease in activity. We therefore assume 14a to be endowed with the correct stereochemistry displaying inhibition potential at the $100 \mathrm{nM}$ level. The exact configuration of 14a was proved by crystallographic data (vide infra). The very strong antibacterial effect of albomycin that was reported in the past also finds an explanation in the preferential uptake of the compound as of its conjugation with the siderophore part. The latter was clearly proven again by Lin et al [15]. 


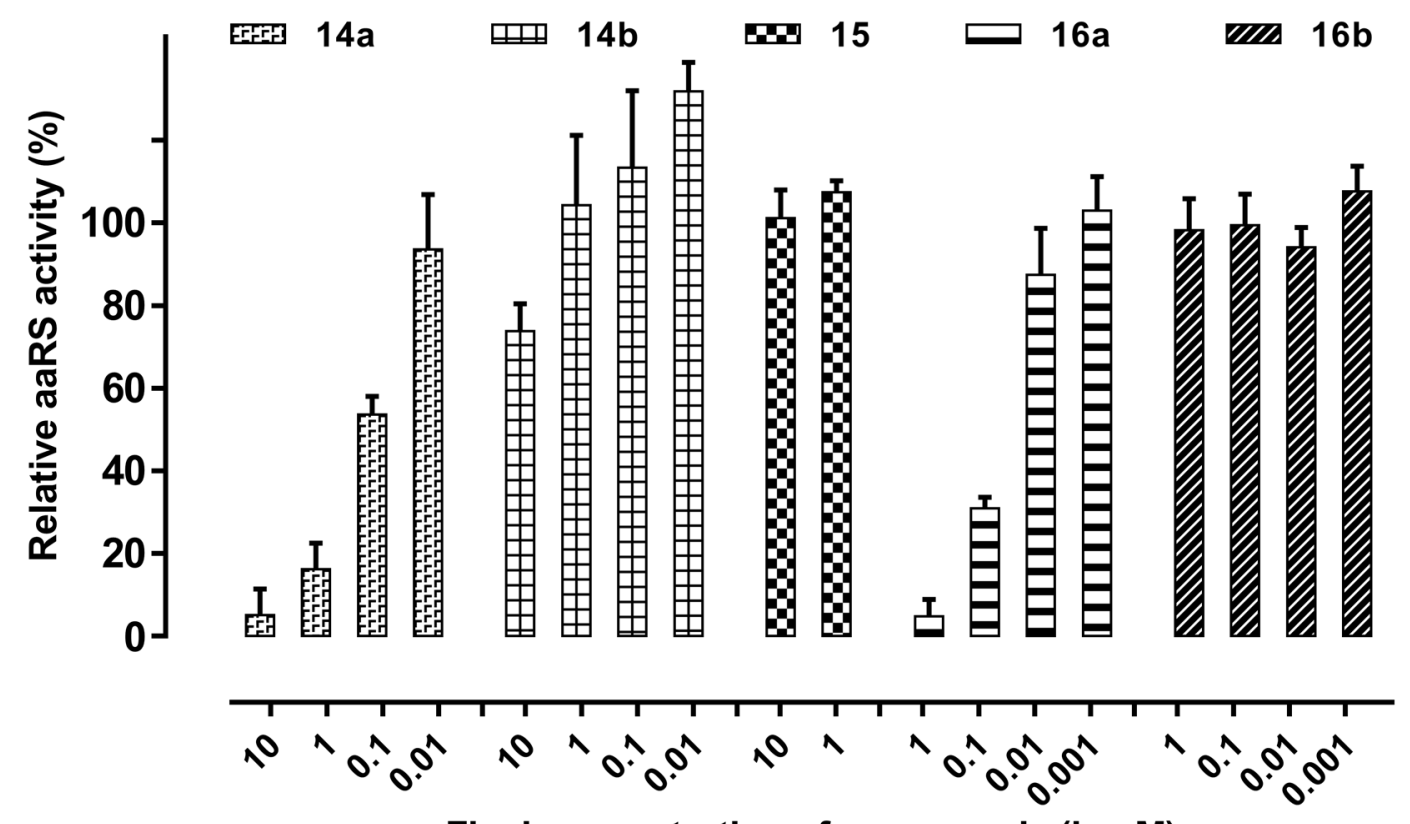

Final concentration of compounds (in $\mu \mathrm{M}$ )

Fig. 2. In vitro inhibitory activity of the obtained isomers on their respective aaRS. Results are expressed as percentage inhibition versus the non-inhibited enzyme. Assay conditions were as described in Nautiyal et al [31].

Our plan was to use the same scaffold for assembling congeners targeting different aaRSs. Thus, we used the scarce material available for synthesizing asp-X (16) targeting the class II AspRS, as well as compound ile-X (15) targeting the class I IleRS. While 16 proved separable in two isomers 16a and 16b in analogy with 14, compound 15 could not be resolved under our analytical conditions and therefore was evaluated as a mixture (approximately 50:50). However, no enzyme inhibitory activity was noted up to $10 \mu \mathrm{M}$ for the ile-X (15) isomeric mixture, meaning the "correct" isomer likewise is devoid of activity up to around $5 \mu \mathrm{M}$. The very different $3 \mathrm{D}$ architecture of the active site for class I and II enzymes has been described many times, and was highlighted again recently in our work on 3-deaza-adenosine inhibitors [30], with complete loss or poor activity upon targeting class II enzymes, while retaining very potent activity versus class I enzymes. Here apparently, the albomycin $\delta 1$ scaffold is not well suited for the class I architecture. Analogously, a 3-methyluracil substitution of adenine in isoleucyl-sulfamoyladenosine by itself already was reported to be detrimental for the strong inhibitory activity of the parent ligand [30]. In contrast, 16a displayed over $60 \%$ inhibitory activity for AspRS at $0.1 \mu \mathrm{M}$ concentration, and 
was still weakly inhibitory even at $10 \mathrm{nM}$. The second isomer $\mathbf{1 6 b}$, as seen with the serine congeners, was completely inactive even at $1 \mu \mathrm{M}$ concentration. The remarkable affinity for AspRS as shown by 16a, albeit carrying a 3-methyluracil base, corresponds with our recent findings on the inhibitory activity of the aspartyl conjugated sulfamoylated 3-methyluridine with an IC 50 of 31 $\mathrm{nM}$ for AspRS [32]. In view of the low amounts of available material, we have not been able to generate dose-response data in order to derive some $\mathrm{K}_{\mathrm{i}}^{\text {app }}$ values, but instead preferred to use the material for soaking into corresponding aaRS crystals to characterize the binding mode of compounds and protein-ligand interactions. Based on the obtained results, we believe the albomycin core scaffold indeed can be used to target class II aaRS, and enzyme inhibitory evaluations allowed us to predict the "correct" stereoisomer.

As described in the introduction, antibacterial activity of these polar warheads can only be attained following attachment of the siderophore part as described many times before. The strong antibacterial activity of the full albomycin structure was recently highlighted again by Lin et al $[15]$.

\section{X-ray crystallographic studies}

To further prove the configuration for the obtained steroisomers of the albomycin derivatives, compounds 14a,b and 16a,b were soaked into Trypanosoma brucei gambiense (Tbg) SerRS and Thermus thermophilus (Tt) AspRS, respectively. The obtained structural data showed unambiguous density for compounds 14a and 16a and we noted the desired 5'S, 6'R chirality. However, for compounds 14b and 16b we only observed electron density for the base moiety, highlighting their reduced affinity for the target enzyme. The results demonstrate that a 5 ' $S, 6^{\prime} R$ configuration for the albomycin core is required for targeting both SerRS and AspRS, which is as found in the genuine albomycin structure. In addition, it proves compounds $\mathbf{1 4 a}$ and 16a have the correct configuration as was already deduced from their more potent inhibitory activity.

\subsection{Structural analysis of protein-ligand interactions for the serine congener $\mathbf{1 4 a}$}

The above-obtained data allowed for structural analysis of 14a and 16a regarding interactions with the target aaRS protein in comparison with the interactions made by the genuine aminocyl-adenylate intermediates, Ser-AMP and Asp-AMP, respectively. Such analysis is highly interesting in view of future inhibitor design, as we are confronted here with a natural inhibitor 
equipped not only with the unusual base 3-methyluracil substituting for adenine, but having as well a thiolated xylofuranosyl sugar ring instead of the ribose, and a one atom shorter carboxylated linker substituting for the phosphate moiety. The overall interactions for the serine containing compounds can be viewed in 2D interaction scheme (Figure 3A) and the Ligplots (Figure SI-1) for both structures 14a and Ser-AMP. Superposition of both ligands is visualized in Figure 3B.
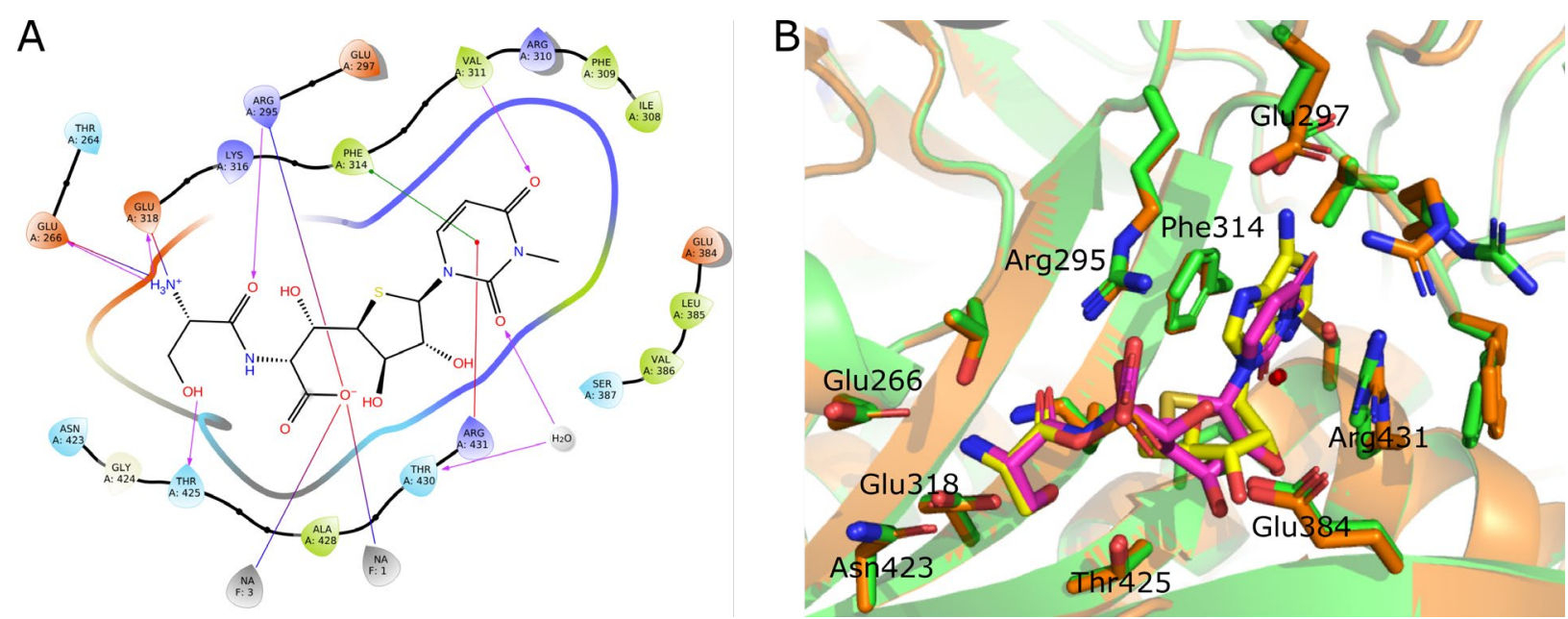

Fig. 3. A: $2 \mathrm{D}$ interaction of Tbg-serRS with 14a. Hydrogen bonds are shown as purple lines. Cation- $\pi$ and $\pi-\pi$ interactions are shown as red and green lines, respectively. Figure generated using Maestro Schrodinger. B: Superposition of Tbg-serRS bound to 14a and ser-AMP. The enzymes are shown as cartoon representations and colored orange and green, respectively. Residues within $5 \AA$ of the compound are shown as stick model. Compound 14a is colored magenta and ser-AMP is colored yellow.

\subsection{Comparison of the heterocyclic base interactions as seen for $14 a$ and Ser-AMP}

With the serine-containing product 14a, the $N^{3}$-methylated uracil base is sandwiched between the Phe314 and Arg431 sidechain for the Tbg-SerRS complex (Figure 3B and for a closeup Figure $4 \mathrm{C}$ ), replicating a $\pi-\pi$ interaction with the aryl ring on one face of the heterocycle and a cation- $\pi$ interaction on the other face. This is analogous to the positioning of the adenine ring in the complex structure of Ser-AMP with SerRS (Figure 4C) [32]. The uracil ring is positioned at the site where the imidazole ring of the adenine base resides, but is tilted around 20 degrees in comparison with the adenine ring plane. The adenine- $N^{9}$ and uracil- $N^{1}$ are almost coinciding. Apart from this $\pi-\pi$ interaction, there are fewer contributions from the modified base with only the $\mathrm{C} 2$ oxygen making a water-bridged interaction with the backbone nitrogen of Arg431, replicating the 
equivalent $N^{3}$-interaction made with adenine. The same water molecule likewise bridges with the backbone nitrogen and hydroxyl substituent of Thr430. For the Ser-AMP compound (Fig 4C) the adenine contributes more to the affinity compared to the methyluracil ring via hydrogen bonding of $N^{3}, N^{6}$ and $N^{1}$, and is likewise sandwiched between Arg431 and Phe314.

\subsection{Comparison of the sugar rings}

As seen from the ligplot (Figure SI-1) and the structural close-up (Figure 4B), each hydroxyl moiety of the 5-membered thioxylofuranosyl ring in 14a interacts with the target enzyme, while except for 3'-OH little interactions are noted for the ribose ring of Ser-AMP. The positions for the sugar carbon atoms deviate substantially for both compounds, with a slight displacement of the xylofuranose ring of 14a towards the serine site compared to the ribose ring in the Ser-AMP structure. The $\mathrm{C} 1$ '-position is already shifted about $1 \AA$ and the further larger thiofuranosyl ring results in C4' of 14a to be positioned almost on the 5'-carbon of Ser-AMP. The 2' and 3' secondary hydroxyl moieties however are largely positioned the same albeit with slightly different orientation. For the thiolated sugar ring this results in a strong H-bond network where the 2'-hydroxyl moiety is binding to the Arg431 side chain and Leu385 carbonyl and where the 3'-OH is H-bonding to the Glu384 side chain. The unsubstituted 5'-OH as seen only in 14a is offset by $2.4 \AA$ versus the 5'oxygen in Ser-AMP, and binds to the same $\varepsilon 2$ oxygen of Glu384 as well as to some water molecules.

The strong structuring of the sugar ring in 14a when in complex with serRS is remarkable and is highlighted as well with the intramolecular H-bonding of 5'-OH with $\mathrm{C6}-\mathrm{H}$ and $\mathrm{C} 3$ '-H (Figure 5A). The thioxylofuranosyl ring in 14a has the 3'-exo conformation (Figure 5B) with a pseudorotation phase angle (P-value) of 186.79, while the seryl-adenylate has the expected 3'-endo conformation of ribonucleosides (Figure 5C) with a P-value of 20.81. The thiolated ring is larger resulting in a $\mathrm{C} 4$ '-C1' distance of $2.7 \AA$, versus $2.3 \AA$ for the ribose ring. 

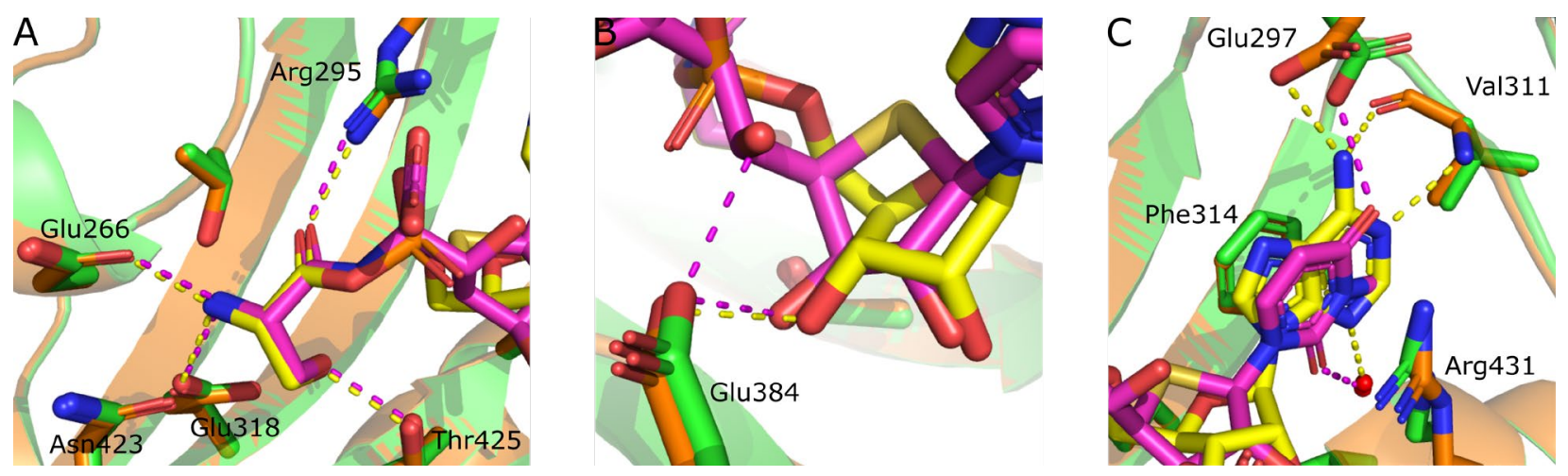

Fig. 4. Interactions of Tbg-serRS with ser-AMP and 14a. The enzymes are shown as cartoon representations and colored orange and green, respectively. Residues within $5 \AA$ of the compound are shown as stick model. The serine congener 14a is colored magenta and ser-AMP is colored yellow. Hydrogen bonds formed between serRS and 14a and ser-AMP are colored magenta and yellow, respectively.
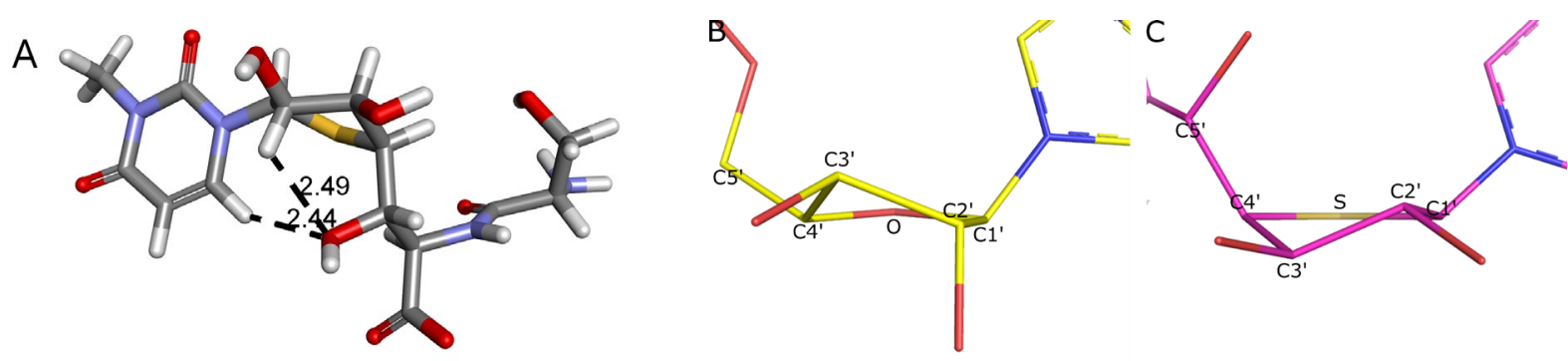

Fig. 5. A. Constrained conformation of 14a via intramolecular H-bonding of the 5'-hydroxyl moiety to C6-H and C3'-H; B. Puckering of seryl-adenylate when in complex with serRS; C. Puckering of the thio-xylofuranosyl ring as seen for 14a (both generated in pymol).

\subsection{Evaluation of the linker parts}

The linker in the albomycin core part connecting the sugar ring to the amino acid carbonyl group is one atom shorter $\left(\mathrm{C}^{\prime}-\mathrm{C} 6^{\prime}-\mathrm{N}\right)$ compared to the natural intermediate (C5'-O-P-O). The former however carries the $5^{\prime}-\mathrm{OH}$ and a 6 '-carboxylate moiety as additional substituents that are anchoring its position. The hydroxyl moiety is bound to Glu384 as mentioned above, while the 6'carboxylate contributes for recognition via an intricate H-bonding network with water molecules directed towards the Arg295 sidechain as well as electrostatic interaction. In analogy, the acylphosphate linkage of the natural enzyme intermediate binds even stronger via an intricate network of multiple H-bonds to Arg295 and Ser387 as well as water mediated interactions with Glu384. In addition, Arg295 likewise is recognizing the serine carbonyl moiety for both ligands. It underlines the importance of Arg295, recognizing both, the phosphate and serine carbonyl in the active 
intermediate Ser-AMP, and binding to the reciprocal 6'-carboxylate and serine carbonyl moiety for the albomycin core structure. As seen in the ligand overlay (SI-2B) and the snapshot for the ligand protein interactions (SI-2C, Figure 4A), the 6'-carboxylate penetrates somewhat deeper into the cavity resulting in a $2.82 \AA \mathrm{H}$-bond length to Arg295, versus $3.26 \AA$ for the reciprocal phosphate, the latter however binding to both terminal nitrogen atoms of Arg295. The linker fragment for 14a has the $\left(5^{\prime} S, 6^{\prime} R\right)-5^{\prime}$-hydroxy-6'-carboxyl stereochemistry (nucleoside numbering as seen in Figure 1, while its diastereomer 14b equipped with a $\left(5^{\prime} R, 6^{\prime} S\right)$-stereochemistry is unable to correctly position the 6'-carboxylate and 5'-OH (based on soaking not providing a clear electron density map). Overall, the shorter linker of the albomycin core structure is compensated by the small shift of the base and sugar ring towards the serine-recognizing pocket. The firm anchoring of the thiosugar and the linker part allow for perfect superposition of the serine part of both molecules (see below).

\subsection{Recognition of the serine part}

In both structures the terminal serine moiety is well recognized, with the serine $\beta$-hydroxyl group being anchored with the Glu318 sidechain and Thr425 hydroxyl group, while the $\alpha$-amine is positioned well via hydrogen bonding with the Thr264 and Glu318 sidechains. Recognition of the carbonyl moiety was already disclosed above. Overall, the position of the serine residues in 14a and in Ser-AMP corresponds entirely upon superposition of both complex structures (Figure 4A). In a supplementary file (SI-Movie) the superimposed ligands 14a and seryl-adenylate are rotated over $360^{\circ}$ allowing inspection and comparison of the subtle changes in orientation of the substituents, and highlighting the deeper positioning towards Arg295 of the 6'-carboxylate versus the phosphate moiety in the natural intermediate.

\subsection{Analogy with the aspartyl congener 16 a}

Coupling of aspartate to the albomycin core structure provided the new congener 16a (and its inactive diastereoisomer 16b), that strongly inhibited AspRS. A complex structure was obtained upon soaking into $T t$-AspRS crystals. Belonging to the same class II family of aaRSs, the interactions of the base part are very similar with those for $\mathbf{1 4 a}$, with a water-mediated bridge from the C2-oxygen to both the backbone NH of Arg531 and sidechain and backbone NH of Asp530 substituting for the threonine interactions as seen for the above serine congener (Figure 6A and 
7C). In this structure, the base is sandwiched via $\pi-\pi$ and cation- $\pi$ interactions mediated by Arg 231 and Phe235. Like with 14a, the uracil base is located at the position of the adenine imidazole ring, with the $N^{3}$-methyl moiety coinciding with the $\mathrm{C} 2$ position of the adenine ring. The sugar ring for this congener is anchored via Arg531 hydrogen bonding to the 2'-hydroxyl and Glu476 sidechain (ع1) stabilization of the 3'- and 5'-hydroxyl group (Figure 7B). The 6'-carboxylate likewise is stabilized as in the serine congener via Arg223 bonding and with weak His442 interaction via its N3-H tautomer.
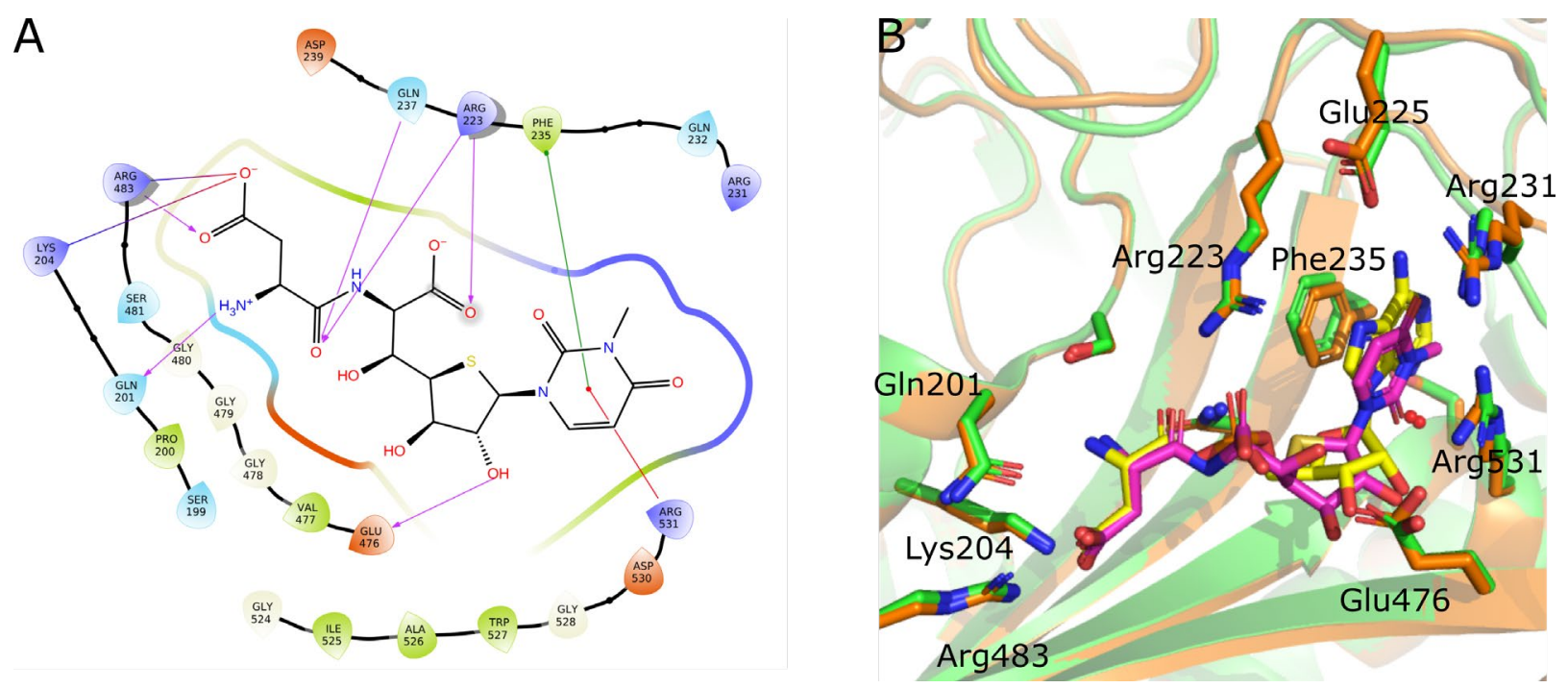

Fig. 6. A: 2D interaction of Tt-aspRS with BG760A. Hydrogen bonds are shown as purple lines. Cation- $\pi$ and $\pi-\pi$ interactions are shown as red and green lines, respectively. Figure generated using Maestro Schrodinger. B: Superposition of Tt-aspRS bound to 16a and asp-AMP. The enzymes are shown as cartoon representations and colored orange and green, respectively. Residues within $5 \AA$ of the compound are shown as stick model. Congener 16a is colored magenta and ser-AMP is colored yellow. Data for Asp-AMP are taken from Poterszman et al. [33]. 

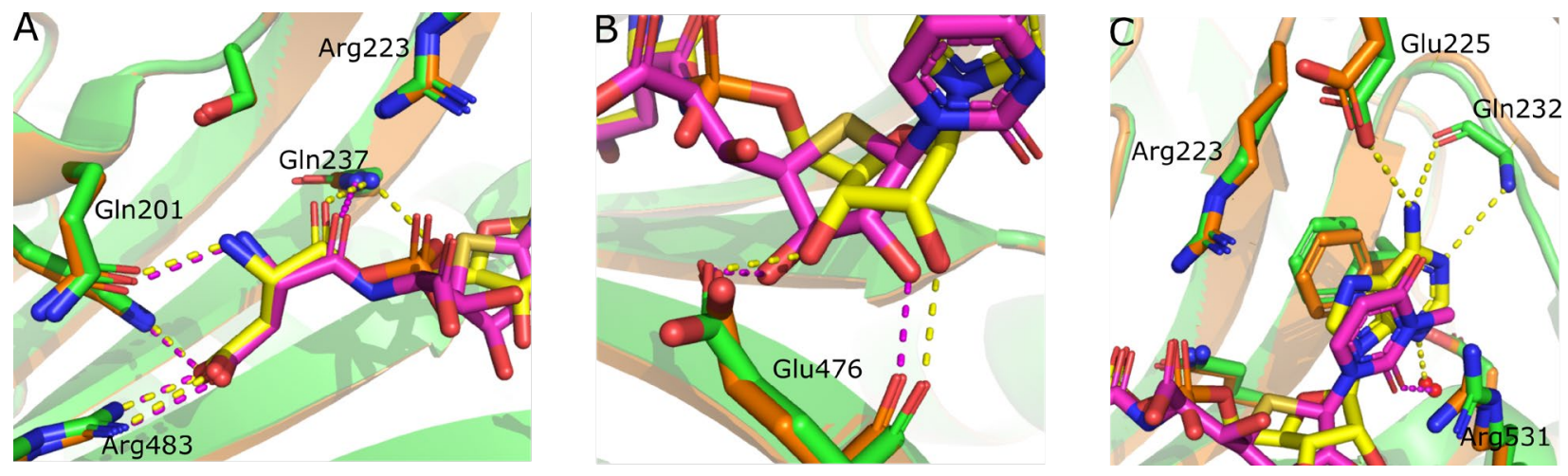

Fig. 7. Interactions of Tt-aspRS with asp-AMP and 16a. The enzymes are shown as cartoon representations and colored orange and green, respectively. Residues within $5 \AA$ of the compound are shown as stick model. Compound 16a is colored magenta and asp-AMP is colored yellow. Hydrogen bonds are colored formed between aspRS and BG760A and asp-AMP are colored magenta and yellow, respectively.

In analogy however with the Asp-AMP structure [33], the terminal aspartate of 16a is strongly structured and held in place via its carbonyl backbone bonding with Arg223 and Gln237 sidechain amide, while the alpha-amine binds with Gln237 and Gln201 (Figure 7A). The terminal carboxylate is strongly positioned via electrostatic interaction with Lys204 and twice with Arg483. In comparison with the 14a complex structure, the sugar and linker parts of the albomycin core for 16a are likewise recognized but a bit less bound apparently. Especially the aspartate recognition boosts the affinity and results in overall slightly higher affinities for 16a over 14a for their respective aaRS target.

\section{Conclusion}

Total synthesis of the core scaffold for the natural product albomycin was accomplished providing a mixture of two diastereomers, and the scaffold was functionalized with the amino acids serine, aspartic acid and isoleucine, followed by isomer separation. The isoleucine containing compound aimed at targeting a class I aaRS, but lacked inhibitory activity, while the serine and aspartic acid congeners having the required 5 ' $S, 6^{\prime} R$-stereochemistry, in contrast displayed strong inhibitory activity. Soaking 14a and 16a in crystals of the corresponding aaRS provided 3D structural information highlighting the tight interaction of the scaffold with class II aaRS enzymes. Overall, we conclude the albomycine core structure is well suited for targeting class II aaRSs and could be used for development of a new family of antibiotics. 


\section{Experimental section}

\subsection{General materials and methods}

Reagents and solvents were purchased from commercial suppliers (Acros, Sigma-Aldrich, Bachem, Novabiochem) and used as provided, unless indicated otherwise. DMF and THF were of analytical grade and were stored over $4 \AA$ molecular sieves. For reactions involving Fmoc-protected amino acids and peptides, DMF for peptide synthesis (low amine content) was used. All other solvents used for reactions were analytical grade and used as provided. Reactions were carried out in oven-dried glassware under a nitrogen atmosphere with stirring at room temperature, unless indicated otherwise. ${ }^{1} \mathrm{H}$ and ${ }^{13} \mathrm{C}$ NMR spectra of the compounds dissolved in $\mathrm{CDCl}_{3}, \mathrm{CD}_{3} \mathrm{OD}$, DMSO- $d_{6}$ or $\mathrm{D}_{2} \mathrm{O}$ were recorded on a Bruker UltraShield Avance $300 \mathrm{MHz}$ or $500 \mathrm{MHz}$ spectrometer. The chemical shifts are expressed as $\delta$ values in parts per million (ppm), using the residual solvent peaks (DMSO: ${ }^{1} \mathrm{H}, 2.50 \mathrm{ppm} ;{ }^{13} \mathrm{C}, 39.52 \mathrm{ppm}$; HOD: ${ }^{1} \mathrm{H}, 4.79 \mathrm{ppm}$ ) as a reference. Coupling constants are given in Hertz $(\mathrm{Hz})$. The peak patterns are indicated by the following abbreviations: $\mathrm{bs}=$ broad singlet, $\mathrm{d}=$ doublet, $\mathrm{m}=$ multiplet, $\mathrm{q}=$ quadruplet, $\mathrm{s}=$ singlet and $\mathrm{t}=$ triplet. High resolution mass spectra were recorded on a quadrupole time-of-flight mass spectrometer (Q-Tof-2, Micromass, Manchester, UK) equipped with a standard ESI interface; samples were infused in 2-propanol/ $\mathrm{H}_{2} \mathrm{O}(1: 1)$ at $3 \mu \mathrm{L} \cdot \mathrm{min}^{-1}$. For TLC, pre-coated aluminium sheets were used (Merck, Silica gel $60 \mathrm{~F}_{254}$ ). The spots were visualized by UV light at $254 \mathrm{~nm}$. Column chromatography was performed on ICN silica gel 60A 60-200. Preparative HPLC of final compound was done using an Adamas C18-X-bond $5 \mu \mathrm{m}$ prep. $(250 \times 10 \mathrm{~mm})$ column connected to a Shimadzu LC-20AT pump using a Shimadzu SPD-20A UV-detector. Recordings were performed at $254 \mathrm{~nm}$ and $214 \mathrm{~nm}$. IUPAC nomenclature is used for the title compounds, but NMR assignments are based on elongated nucleoside structures for convenience and consistency with the basic starting blocks.

\subsection{Methyl- $\beta$-L-arabinopyranoside (3) [19, 20]}

Acetyl chloride $(42.5 \mathrm{~mL}, 588 \mathrm{mmol})$ was added dropwise to methanol $(450 \mathrm{~mL})$ at $0{ }^{\circ} \mathrm{C}$. Next, L-arabinose (100 g, $666 \mathrm{mmol})$ was added in three portions. The suspension was maintained at $0{ }^{\circ} \mathrm{C}$ for $1 \mathrm{~h}$ and then heated to $55^{\circ} \mathrm{C}$ for $4 \mathrm{~h}$. After cooling it to room temperature, the reaction mixture was poured into a mixture of hexane: $\operatorname{Et}_{2} \mathrm{O}(1: 1 \mathrm{v} / \mathrm{v}, 1 \mathrm{~L})$. The precipitate was filtered off 
and washed with a mixture of hexane: $\mathrm{Et}_{2} \mathrm{O}(1: 1 \mathrm{v} / \mathrm{v})$. The precipitate was collected, washed with

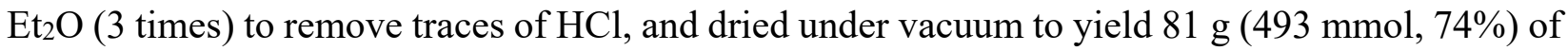
methyl arabinopyranoside 3 as a white solid. ${ }^{1} \mathrm{H}$ NMR $\left(300 \mathrm{MHz}, \mathrm{CD}_{3} \mathrm{OD}\right) \delta 3.38\left(\mathrm{~s}, \mathrm{OCH}_{3}\right), 3.55$ $(\mathrm{dd}, 1 \mathrm{H}, J=12.3$ and $2.3 \mathrm{~Hz}), 3.73-3.81(\mathrm{~m}, 3 \mathrm{H}), 3.82-3.86(\mathrm{~m}, 1 \mathrm{H}), 4.66(\mathrm{~d}, 1 \mathrm{H}, J=2.9 \mathrm{~Hz}, \mathrm{H}-$ 1); ${ }^{13} \mathrm{C}$ NMR (75 MHz, CD $\left.3 \mathrm{OD}\right) \delta 55.8\left(\mathrm{OCH}_{3}\right), 63.9$ (C-5), 70.3 (C-3), 70.7 (C-2), 70.8 (C-4), 102.0 (C-1); HRMS for $\mathrm{C}_{6} \mathrm{H}_{12} \mathrm{O}_{5} \mathrm{Na}[\mathrm{M}+\mathrm{Na}]^{+}$calcd.: 187.0577 ; found: 187.0586

\subsection{Tosylation of L- $\beta$-arabinopyranoside (4 and 5) [21, 22]}

A mixture of 3 ( $1 \mathrm{~g}, 6.09 \mathrm{mmol})$ and dibutyltin oxide (1.52 g, $6.09 \mathrm{mmol}, 1.0$ eq.) in dry methanol $(25 \mathrm{~mL})$ was heated to reflux for overnight. Next, the solvent was evaporated to dryness and the residue was co-evaporated with dioxane ( 3 times) to remove traces of methanol. The oily residue was suspended in dry dioxane $(25 \mathrm{~mL})$ along with DMAP (149 $\mathrm{mg}, 1.22 \mathrm{mmol})$ and cooled to $0{ }^{\circ} \mathrm{C}$, after which a solution of tosyl chloride $(1.23 \mathrm{~g}, 6.7 \mathrm{mmol}, 1.1$ equivalent $)$ in dry dioxane $(5 \mathrm{~mL})$ was added dropwise. Next, the ice bath was removed and the reaction mixture was stirred at room temperature for $30 \mathrm{~h}$. The solvent was evaporated to dryness and the products were purified by column chromatography to yield $300 \mathrm{mg}$ (0.94 mmol, 16\%) 3-O-tosyl (4) and $889 \mathrm{mg}(2.79$ mmol, 46\%) 4-O-tosyl product (5). Both products were obtained as white solids.

Methyl-3-O-tosyl- $\beta$-L-arabinopyranoside (4): ${ }^{1} \mathrm{H}$ NMR $\left(600 \mathrm{MHz}, \mathrm{CDCl}_{3}\right) \delta 1.93(\mathrm{~d}, 1 \mathrm{H}, J=10.0$ $\mathrm{Hz}, 2-\mathrm{OH}), 2.45$ (s, 3H, Tosyl- $\left.\mathrm{CH}_{3}\right), 2.51$ (bs, 1H, 4-OH), 3.41 (s, 3H, OCH3), 3.72 (dd, 1H, J= $2.3 \mathrm{~Hz}$ and $12.6 \mathrm{~Hz}, \mathrm{H}-5 \mathrm{a}), 3.78(\mathrm{~d}, 1 \mathrm{H}, J=12.6 \mathrm{~Hz}, \mathrm{H}-5 \mathrm{~b}), 4.00(\mathrm{td}, 1 \mathrm{H}, J=3.8 \mathrm{~Hz}$ and $9.9 \mathrm{~Hz}$, H-2), 4.15-4.18 (m, 1H, H-4), 4.67 (dd, 1H, $J=3.2 \mathrm{~Hz}$ and 9.8 Hz, H-3), 4.79 (d, 1H, $J=3.8 \mathrm{~Hz}$, $\mathrm{H}-1), 7.34$ (m, 2H, meta-H, Ts), 7.84-7.87 (m, 2H, ortho-H, Ts); $\left.{ }^{13} \mathrm{C} \mathrm{NMR} \mathrm{(150} \mathrm{MHz,} \mathrm{CDCl}_{3}\right) \delta$ $21.7\left(p-\mathrm{Ts}^{-} \mathrm{CH}_{3}\right), 55.6\left(\mathrm{OCH}_{3}\right), 61.9(\mathrm{C}-5), 66.8$ (C-2), $68.6(\mathrm{C}-4), 77.2$ (C-3) $100.0(\mathrm{C}-1), 127.9$ (meta-C, Ts), 129.9 (ortho-C, Ts), 133,4 (para-C, Ts)145.2 (ipso-C, Ts); HRMS for $\mathrm{C}_{13} \mathrm{H}_{22} \mathrm{O}_{7} \mathrm{SN}$ [M+NH$]^{+}$calcd.: 336.1116; found: 336.1109 .

Methyl-4- $O$-tosyl- $\beta$-L-arabinopyranoside (5): ${ }^{1} \mathrm{H}$ NMR $\left(600 \mathrm{MHz}, \mathrm{CDCl}_{3}\right) \delta 2.28-2.33$ (m, $1 \mathrm{H}, 2$ $\mathrm{OH}), 2.45$ (s, 3H, Tosyl- $\left.\mathrm{CH}_{3}\right), 2.54-2.58(\mathrm{~m}, 1 \mathrm{H}, 3-\mathrm{OH}), 3.41\left(\mathrm{~s}, 3 \mathrm{H}, \mathrm{OCH}_{3}\right), 3.74-3.79$ (m, 3H, H3 and H-5), 3.85-3.89 (m, 1H, H-2), 4.78 (d, 1H, J=3.6 Hz, H-1), 4.82-4.84 (m, 1H, H-4), 7.35 (d, $2 \mathrm{H}, J=7.8 \mathrm{~Hz}$, meta-H, Ts), 7.84 (d, $2 \mathrm{H}, J=8.4 \mathrm{~Hz}$, ortho-H, Ts); $\left.{ }^{13} \mathrm{C} \mathrm{NMR} \mathrm{(150} \mathrm{MHz,} \mathrm{CDCl}_{3}\right)$ $\delta 21.7\left(\mathrm{Ts}^{\left.-\mathrm{CH}_{3}\right),} 55.8(\mathrm{C}-5), 60.7\left(\mathrm{OCH}_{3}\right), 68.6(\mathrm{C}-3), 69.5(\mathrm{C}-2), 78.8(\mathrm{C}-4), 78.8(\mathrm{C}-4), 99.5(\mathrm{C}-\right.$ 
1), 127.9 (meta-C, Ts), 129.9 (ortho-C, Ts), 133.5 (para-C, Ts), 145.1 (ipso-C, Ts); HRMS for $\mathrm{C}_{13} \mathrm{H}_{22} \mathrm{O}_{7} \mathrm{SN}\left[\mathrm{M}+\mathrm{NH}_{4}\right]^{+}$calcd.: 336.1116; found: 336.1101 .

\subsection{Methyl-2,3-di-O-benzoyl-4-O-tosyl- $\beta$-L-arabinopyranoside (6) [24]}

To an ice cooled solution of 5 (37.4 g, $117.48 \mathrm{mmol})$ and DMAP $(2.87 \mathrm{~g}, 23.5 \mathrm{mmol})$ in dry pyridine $(600 \mathrm{~mL})$ was added dropwise a mixture of benzoyl chloride $(54.6 \mathrm{~mL}, 469.9 \mathrm{mmol})$ in dry pyridine $(100 \mathrm{~mL})$ over a period of $1.5 \mathrm{~h}$. After $30 \mathrm{~min}$, the ice bath was removed and the reaction mixture was stirred at room temperature for $24 \mathrm{~h}$. Next, the excess of benzoyl chloride was quenched by adding saturated $\mathrm{NaHCO}_{3}(1 \mathrm{~L})$ dropwise. The solvent was evaporated to dryness and the residue was partitioned between saturated $\mathrm{NaHCO}_{3}(1 \mathrm{~L})$ and ethyl acetate $(1 \mathrm{~L})$. The layers were separated and the aqueous layer was further washed with ethyl acetate $(2 \times 500 \mathrm{~mL})$. The organic layer was collected, dried over $\mathrm{Na}_{2} \mathrm{SO}_{4}$, filtered and evaporated to dryness. The crude yellow residue was subjected to column chromatography to yield $56.8 \mathrm{~g}(107.87 \mathrm{mmol}, 92 \%)$ of di- $O$-benzoylated product 6 as a white solid. ${ }^{1} \mathrm{H}$ NMR $\left(600 \mathrm{MHz}, \mathrm{CDCl}_{3}\right) \delta 2.17\left(\mathrm{~s}, 3 \mathrm{H}, \mathrm{Ts}-\mathrm{CH}_{3}\right)$, 3.42 (s, 3H, $\mathrm{OCH}_{3}$ ), 3.96-4.05 (m, 2H, H-5), 5.08 (bs, 1H, H-4), 5.14 (d, 1H, J = 3.0 Hz, H-1), 5.59 (t, 2H, J = 2.4 Hz, H-2 and H-3), 6.94-6.97 (m, 2H, ortho-H, Ts), 7.33-7.36 (m, 4H, Bz), 7.48-7.53 (m, 2H, Bz), 7.65-7.68 (m, 2H, meta-H, Ts), 7.75-7.78 (m, 2H, Bz), 7.93-7.95 (m, 2H, Bz); ${ }^{13} \mathrm{C}$ NMR (150 MHz, $\left.\mathrm{CDCl}_{3}\right) \delta 55.8\left(\mathrm{OCH}_{3}\right), 60.6$ (C-5), 67.8 (C-3), 68.4 (C-2), 76.8 (C-4), 97.7 (C1), 127.7, 128.2, 128.4, 128.8, 129.2, 129.7, 129.78, 129.80, 133.1, 133.28, 133.29, 144.7 (aromatic), 165.5, $165.7(\mathrm{C}=\mathrm{O}, \mathrm{Bz})$; $\mathrm{HRMS}$ for $\mathrm{C}_{27} \mathrm{H}_{30} \mathrm{O}_{9} \mathrm{SN}\left[\mathrm{M}+\mathrm{NH}_{4}\right]^{+}$calcd.: 544.1641; found: 544.1631.

\subsection{Methyl-2,3-di-O-benzoyl-4-deoxy-4-thioacetyl- $\alpha$-D-xylopyranoside (7) $[25,26]$}

A solution of $6(55.5 \mathrm{~g}, 105 \mathrm{mmol})$ and potassium thioacetate $(30.15 \mathrm{~g}, 264 \mathrm{mmol})$ in dry DMF $(600 \mathrm{~mL})$ was stirred at $80{ }^{\circ} \mathrm{C}$ for $6 \mathrm{~h}$. Although, TLC indicated incomplete reaction, the reaction was stopped due to formation of undesired products. Next, the solvent was evaporated to dryness. The dark brown residue was partitioned between water $(0.5 \mathrm{~L})$ and DCM $(0.5 \mathrm{~L})$. The aqueous layer was further washed with DCM $(3 \times 300 \mathrm{~mL})$. The combined DCM layer was washed with saturated $\mathrm{NaCl}$ solution. The organic layer was collected, dried over anhydrous $\mathrm{Na}_{2} \mathrm{SO}_{4}$, filtered and evaporated to dryness. The brown residue was subjected to silica gel chromatography to yield $23.1 \mathrm{~g}$ (53.66 mmol, 51\%) of 4-thio-xylopyranoside 7 as white solid. In addition, $26.2 \mathrm{~g}$ 
(49.76 mmol, 47\%) of starting 4-O-tosyl derivative 6 was recovered as pale yellow solid. ${ }^{1} \mathrm{H}$ NMR $\left(600 \mathrm{MHz}, \mathrm{CDCl}_{3}\right) \delta 2.26$ (s, 3H, $\left.\mathrm{SCOCH}_{3}\right), 3.41$ (s, 3H, OCH3), 3.76-3.82 (m, 2H, H-5), 4.034.09 (m, 1H, H-4), 5.15 (d, 1H, $J=3.5 \mathrm{~Hz}, \mathrm{H}-1), 5.23$ (dd, $1 \mathrm{H}, J=3.5 \mathrm{~Hz}$ and $9.8 \mathrm{~Hz}, \mathrm{H}-2), 5.82$ (dd, $1 \mathrm{H}, J=9.8 \mathrm{~Hz}$ and $11.3 \mathrm{~Hz}, \mathrm{H}-3$ ), 7.34-7.39 (m, 4H, Bz), 7.47-7.51 (m, 2H, Bz), 7.94-7.97 (m, 4H, Bz); ${ }^{13} \mathrm{C}$ NMR $\left(150 \mathrm{MHz}, \mathrm{CDCl}_{3}\right) \delta 30.7\left(\mathrm{SCOCH}_{3}\right), 43.2(\mathrm{C}-4), 55.5\left(\mathrm{OCH}_{3}\right), 60.5(\mathrm{C}-$ 5), 68.4 (C-3), 73.3 (C-2), 97.6 (C-1), 128.3, 128.4, 129.1, 129.2, 129.8, 133.2, 133.3 (aromatic), 165.75, 165,80 (C=O, Bz), $193.6\left(\mathrm{SCOCH}_{3}\right)$; HRMS for $\mathrm{C}_{22} \mathrm{H}_{22} \mathrm{O} \mathrm{O}_{7} \mathrm{SNa}[\mathrm{M}+\mathrm{Na}]^{+}$calcd.: 453.0979; found: 453.0975 .

\subsection{1,5-di-O-acetyl-2,3-di-O-benzoyl-4-deoxy-4-thio- $\alpha / \beta$-D-xylofuranose (8) [25, 27]}

A mixture of AcOH:Ac $2 \mathrm{O}$ :conc. $\mathrm{H}_{2} \mathrm{SO}_{4}(10: 10: 1 \mathrm{v} / \mathrm{v} / \mathrm{v}, 462 \mathrm{~mL})$ was added to thioacetate derivative $7(35.1 \mathrm{~g}, 81.54 \mathrm{mmol})$ while maintaining below $-10^{\circ} \mathrm{C}$. The reaction mixture was stirred at $-10{ }^{\circ} \mathrm{C}$ for $10 \mathrm{~min}$. and was allowed to stand at $+4{ }^{\circ} \mathrm{C}$ for overnight. Next, sodium acetate $(30 \mathrm{~g})$ was added at $0{ }^{\circ} \mathrm{C}$. The reaction mixture was then neutralized very slowly by addition of saturated $\mathrm{NaHCO}_{3}$ to reach $\mathrm{pH} 8$ (over 3-4 h). It was extracted with ethyl acetate $(3 \times 1 \mathrm{~L})$. The combined organic layer was further washed with saturated $\mathrm{NaCl}$. The organic layer was collected, dried over $\mathrm{Na}_{2} \mathrm{SO}_{4}$, filtered and evaporated to dryness. The dark yellow viscous oil was purified by silica gel chromatography to obtain $28.1 \mathrm{~g}(61.35 \mathrm{mmol}, 75 \%)$ of xylofuranose derivative as a mixture of $\alpha / \beta$ anomers of 8. HRMS for $\mathrm{C}_{23} \mathrm{H}_{22} \mathrm{O}_{8} \mathrm{SNa}[\mathrm{M}+\mathrm{Na}]^{+}$calcd.: 481.0928; found: 481.0927 .

\section{7. $N^{1}$-(5-O-acetyl-2,3-di-O-benzoyl-4-deoxy-4-thio- $\beta$-D-xylofuranos-1-yl)-uracil (9)}

To a solution of uracil ( $8.13 \mathrm{~g}, 72.5 \mathrm{mmol}, 1.2 \mathrm{eq}$.) in dry ACN $(100 \mathrm{~mL})$ was dropwise added BSA (59.1 mL, $241.7 \mathrm{mmol}, 4$ eq.). The reaction mixture being a suspension was heated to $80{ }^{\circ} \mathrm{C}$ for 45 min. during which it became clear. It was then cooled to room temperature and a solution of thiofuranose 8 in $\mathrm{ACN}(27.7 \mathrm{~g}, 60.42 \mathrm{mmol})$ was added dropwise. Next a solution of $\mathrm{SnCl}_{4}(1 \mathrm{M}, 181.1 \mathrm{~mL}, 181.1 \mathrm{mmol}, 3 \mathrm{eq}$.) was added dropwise. The reaction mixture was stirred at $40{ }^{\circ} \mathrm{C}$ for overnight after which it was cooled to room temperature and quenched by addition of saturated $\mathrm{NaHCO}_{3}(\mathrm{pH} \sim 8)$. The gelatinous precipitate was filtered off through Celite ${ }^{\circledR} 545$. The filtrate was transferred to a separating funnel and washed with DCM $(3 \times 0.5 \mathrm{~L})$. The organic layer was further washed with brine. The DCM layer was collected, dried over anhydrous $\mathrm{Na}_{2} \mathrm{SO}_{4}$, filtered and evaporated to dryness. The product was purified by column chromatography to afford

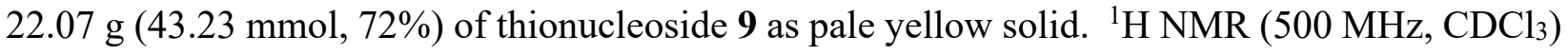


$\delta 2.01$ (s, 3H, $\left.\mathrm{COCH}_{3}\right), 4.09-4.17$ (m, 1H, H-4'), 4.36 (dd, $1 \mathrm{H}, J=5.8 \mathrm{~Hz}$ and $11.91 \mathrm{~Hz}, \mathrm{H}-5$ 'a), 4.56 (dd, $1 \mathrm{H}, J=5.1 \mathrm{~Hz}$ and $11.88 \mathrm{~Hz}, \mathrm{H}-5$ 'b), 5.83-5.90 (m, 2H, H-5 and H-3'), 6.04 (t, 1H, $J=$ $6.7 \mathrm{~Hz}, \mathrm{H}-4$ '), 6.45 (d, 1H, J = 6.6 Hz, H-1'), 7.38-7.45 (m, 4H, Bz, 7.52-7.60 (m, 2H, Bz), 7.918.00 (m, 4H, Bz), 8.04 (d, 1H, $J=8.2 \mathrm{~Hz}, \mathrm{H}-6), 9.37$ (s, $1 \mathrm{H}, \mathrm{N} H) ;{ }^{13} \mathrm{C} \mathrm{NMR}\left(125 \mathrm{MHz}, \mathrm{CDCl}_{3}\right) \delta$ $20.7\left(\mathrm{COCH}_{3}\right), 43.3$ (C-4'), 59.4 (C-1'), 63.4 (C-5'), 74.4 (C-3'), 77.4 (C-2'), 103.7 (C-5), 128.3, 128.4, 128.5, 128.6, 128.7, 129.7, 129.8, 129.86, 129.89, 130.0, 133.8, 134.0 (aromatic), 140.1 (C6), $150.6(\mathrm{C}-2), 162.5(\mathrm{C}-4), 165.2(\mathrm{C}=\mathrm{O}, \mathrm{Bz}), 165.4(\mathrm{C}=\mathrm{O}, \mathrm{Bz}), 170.0(\mathrm{C}=\mathrm{O}, \mathrm{Ac})$; HRMS for $\mathrm{C}_{25} \mathrm{H}_{23} \mathrm{~N}_{2} \mathrm{O} 8 \mathrm{~S}[\mathrm{M}+\mathrm{H}]^{+}$calcd.: 511.1169; found: 511.1169 .

6.8. $\quad N^{3}$-methyl-[N-(5-O-acetyl-2,3-di-O-benzoyl-4-deoxy-4-thio- $\beta$-D-xylofuranos-1-yl)]-uracil (10)

Compound 9 (21.9 g, $42.90 \mathrm{mmol})$ and $\mathrm{K}_{2} \mathrm{CO}_{3}(17.79 \mathrm{~g}, 128.7 \mathrm{mmol}, 3 \mathrm{eq}$.) were suspended in a mixture of dry DMF: acetone $(1: 1 \mathrm{v} / \mathrm{v}, 400 \mathrm{~mL})$ to which methyl iodide $(2.67 \mathrm{~mL}, 42.90 \mathrm{mmol}$, 1 eq.) was added dropwise. The suspension was heated to reflux $\left(70^{\circ} \mathrm{C}\right)$ for overnight. Next, the solvent was evaporated under reduced pressure. The residue was partitioned between water (500 $\mathrm{mL})$ and EtOAc $(500 \mathrm{~mL})$. The layers were separated and the aqueous layer was further washed with ethyl acetate $(3 \times 500 \mathrm{~mL})$. The combined organic layer was further washed with brine. The organic layer was collected, dried over $\mathrm{Na}_{2} \mathrm{SO}_{4}$, filtered and evaporated to dryness. The product

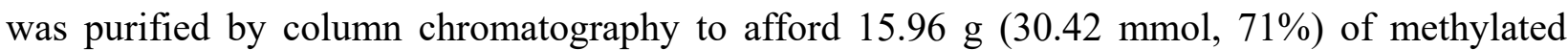
derivative 10 as pale yellow semisolid. Protocol adapted from ref [28]. ${ }^{1} \mathrm{H}$ NMR (500 MHz, $\left.\mathrm{CDCl}_{3}\right) \delta 2.02$ (s, 3H, $\mathrm{COCH}_{3}$ ), 3.27 (s, 3H, NCH3), 4.16 (q, $1 \mathrm{H}, J=6.0 \mathrm{~Hz}, \mathrm{H}-4$ '), 4.38 (dd, $1 \mathrm{H}$, $J=5.9 \mathrm{~Hz}$ and $11.8 \mathrm{~Hz}, \mathrm{H}-5$ 'a), $4.55\left(\mathrm{dd}, 1 \mathrm{H}, J=5.2 \mathrm{~Hz}\right.$ and $\left.11.8 \mathrm{~Hz}, \mathrm{H}-5{ }^{\prime} \mathrm{b}\right), 5.83-5.92(\mathrm{~m}, 2 \mathrm{H}$, H-5 and H-3'), 6.01-6.07 (m, 1H, H-2'), 6.50 (d, 1H, $J=6.2$ Hz, H-1'), 7.40-7.46 (m, 4H, Bz), 7.55-7.61 (m, 2H, Bz), 7.92-8.04 (m, 5H, Bz and H-6); ${ }^{13} \mathrm{C}$ NMR $\left(125 \mathrm{MHz}, \mathrm{CDCl}_{3}\right) \delta 20.7$ $\left(\mathrm{COCH}_{3}\right), 28.1\left(\mathrm{NCH}_{3}\right), 43.8$ (C-4'), 60.7 (C-1'), 63.4 (C-5'), 74.6 (C-3'), 78.2 (C-2'), 103.0 (C5), 128.3, 128.4, 128.6, 128.7, 129.8, 130.0, 133.9, 134.0 (aromatic), 137.9 (C-6), 151.6 (C-2), 162.2 (C-4), 165.2, $165.3(\mathrm{C}=\mathrm{O}, \mathrm{Bz}), 170.0(\mathrm{C}=\mathrm{O}, \mathrm{Ac})$; HRMS for $\mathrm{C}_{26} \mathrm{H}_{25} \mathrm{~N}_{2} \mathrm{O}_{8} \mathrm{~S}[\mathrm{M}+\mathrm{H}]^{+}$calcd.: 525.1326; found: 525.1341 .

6.9. $N^{3}$-methyl-[N-(2,3-di-O-benzoyl-4-deoxy-4-thio- $\beta$-D-xylofuranos-1-yl)]-uracil (11)

The methylated nucleoside derivative 10 (15.86 g, $30.24 \mathrm{mmol}$ ) was dissolved in a mixture of DCM:MeOH $(1: 1 \mathrm{v} / \mathrm{v}, 400 \mathrm{~mL})$ and cooled to $0{ }^{\circ} \mathrm{C}$. Hereto, acetyl chloride $(21.6 \mathrm{~mL}, 302 \mathrm{mmol}$, 
10 eq.) was added dropwise. After $15 \mathrm{~min}$, the ice bath was removed and the reaction mixture was stirred at room temperature for overnight. The reaction mixture was cooled again to $0{ }^{\circ} \mathrm{C}$ and quenched by addition of saturated $\mathrm{NaHCO}_{3}(\mathrm{pH} \sim 8)$. The volatiles were removed by evaporation and the aqueous layer was extracted with DCM $(3 \times 500 \mathrm{~mL})$. The combined organic layer was washed with saturated $\mathrm{NaCl}$. The organic layer was collected, dried over anhydrous $\mathrm{Na}_{2} \mathrm{SO}_{4}$, filtered and evaporated to dryness. The product was isolated by column chromatography to yield $13.0 \mathrm{~g}(26.94 \mathrm{mmol}, 89 \%)$ of deacetylated product 11 as a white solid. ${ }^{1} \mathrm{H}$ NMR ( $\left.300 \mathrm{MHz}, \mathrm{CDCl}_{3}\right)$ $\delta 2.83$ (s, $\left.1 \mathrm{H}, 5^{\prime}-\mathrm{OH}\right), 3.27$ (s, 3H, $\mathrm{NCH}_{3}$ ), 3.81-3.89 (m, 1H, H-5'a), 3.90-3.97 (m, 1H, $J=6.6 \mathrm{~Hz}$, H-4'), 4.02-4.17 (m, 1H, H-5'b), 5.85 (t, 1H, $J=6.9$ Hz, H-3'), 5.93 (d, 1H, $J=8.1 \mathrm{~Hz}, \mathrm{H}-5$ ), 6.27 (t, 1H, $J=6.6 \mathrm{~Hz}, \mathrm{H}-2$ '), 6.49 (d, 1H, $J=6.3 \mathrm{~Hz}, \mathrm{H}-1$ '), $7.30-7.47$ (m, 4H, Bz), 7.48-7.61 (m, 2H, Bz), 7.91 (d, 2H, $J=7.5 \mathrm{~Hz}, \mathrm{Bz}), 8.02$ (d, 2H, $J=7.2 \mathrm{~Hz}, \mathrm{Bz}), 8.47$ (d, $1 \mathrm{H}, J=8.1 \mathrm{~Hz}, \mathrm{H}-6) ;{ }^{13} \mathrm{C}$ NMR (75 MHz, $\left.\mathrm{CDCl}_{3}\right) \delta 28.0\left(\mathrm{NCH}_{3}\right), 46.4$ (C-4'), 59.9 (C-4'), 59.9 (C-1'), 61.4 (C-5'), 75.4 (C3'), 78.4 (C-2'), 102.8 (C-5), 128.45, 128.53, 128.6, 129.9, 133.6, 133.9 (aromatic), 139.3 (C-6), 151.8 (C-2), $163.0(\mathrm{C}-4), 165.4,165.7(\mathrm{C}=\mathrm{O}, \mathrm{Bz})$; HRMS for $\mathrm{C}_{24} \mathrm{H}_{23} \mathrm{~N}_{2} \mathrm{O}_{7} \mathrm{~S}[\mathrm{M}+\mathrm{H}]^{+}$calcd: 483.1220 found 483.1223 .

6.10. (2R,3S)-2-bis-(tert-butyloxycarbonyl)-amino-3-((2R,3R,4R,5R)-3,4-di-benzoyloxy-5-(3methyl-2,4-dioxo-3,4-dihydropyrimidin-1(2H)-yl)tetrahydrothiophen-2-yl)-3-hydroxypropanoic acid methyl ester and its $(2 S, 3 R)$ diastereoisomer (12)

To an ice cooled solution of alcohol 11 (2 g, $4.14 \mathrm{mmol}, 1.0$ eq.) in dry DCM $(50 \mathrm{~mL})$ was added dropwise a solution of Dess-Martin reagent (15\% w/v, $17.6 \mathrm{~mL}, 6.21 \mathrm{mmol}, 1.5$ equiv.) and the reaction mixture was stirred at $0{ }^{\circ} \mathrm{C}$ for $3 \mathrm{~h}$. The reaction was quenched by simultaneous addition of saturated $\mathrm{NaHCO}_{3}$ and $10 \%$ sodium thiosulphate. The biphasic mixture was vigorously stirred for additional $7 \mathrm{~min}$. The layers were separated and the aqueous layer was extracted with DCM $(2 \times 300 \mathrm{~mL})$. The combined organic layer was washed with saturated $\mathrm{NaCl}$ and collected, dried over $\mathrm{Na}_{2} \mathrm{SO}_{4}$, filtered and evaporated to dryness. The crude aldehyde was used without further purification.

$N^{3}$-methyl-[ $N^{I}$-(2,3-di-O-benzoyl-4-deoxy-4-thio-5-aldehyde- $\beta$-D-xylofuranos-1-yl)]-uracil: $\quad{ }^{1} \mathrm{H}$ NMR (300 MHz, $\left.\mathrm{CDCl}_{3}\right) \delta 3.28$ (s, 3H, NCH3), 4.61 (dd, $1 \mathrm{H}, J=1.9 \mathrm{~Hz}$ and $6.8 \mathrm{~Hz}, \mathrm{H}-4$ '), 5.956.07 (m, 2H, H-5, H-3'), 6.15-6.21 (m, 1H, H-2'), 6.56 (d, 1H, J = 6.4 Hz, H-1'), 7.38-7.47 (m, 4H, Bz), 7.54-7.62 (m, 2H, Bz), 7.91-8.01 (m, 5H, Bz and H-6), 9.92 (s, 1H, CHO); ${ }^{13} \mathrm{C}$ NMR (75 
$\left.\mathrm{MHz}, \mathrm{CDCl}_{3}\right) \delta 28.0\left(\mathrm{NCH}_{3}\right), 51.1$ (C-4'), 60.6 (C-1'), 74.6 (C-3'), 77.3 (C-2' merged in solvent peak), 103.6 (C-5), 128.6, 128.7, 129.8, 129.9, 134.1 (Bz), 138.1 (C-6), 151.6 (C-2), 162.2 (C-4), 165.22, $165.25(\mathrm{C}=\mathrm{O}, \mathrm{Bz}), 194.6(\mathrm{CHO})$.

In a separate vessel, $\mathrm{nBuLi}(2.5 \mathrm{M}, 3.4 \mathrm{~mL}, 8.28 \mathrm{mmol})$ in dry THF $(50 \mathrm{~mL})$ was cooled to $0{ }^{\circ} \mathrm{C}$ (ice-bath). To this solution, DIPEA $(1.2 \mathrm{~mL}, 8.28 \mathrm{mmol})$ was added slowly. The reaction mixture was stirred at $0{ }^{\circ} \mathrm{C}$ for $30 \mathrm{~min}$ and at room temperature for $15 \mathrm{~min}$., and cooled again to $78^{\circ} \mathrm{C}$. Then a solution of Boc 2 GlyOMe $(2.4 \mathrm{~g}, 8.28 \mathrm{mmol})$ in dry THF $(20 \mathrm{~mL})$ was added dropwise over a period of $10 \mathrm{~min}$. The reaction mixture was stirred at $-78^{\circ} \mathrm{C}$ for $2 \mathrm{~h}$. Next, the solution of crude aldehyde $(4.14 \mathrm{mmol})$ in dry THF $(50 \mathrm{~mL})$ was added dropwise over a period of $15 \mathrm{~min}$. and the reaction mixture was stirred at $-78^{\circ} \mathrm{C}$ for an additional $1 \mathrm{~h}$. After completion, it was quenched by addition of glacial $\mathrm{AcOH}(100 \mathrm{~mL})$ and was allowed to warm to room temperature while stirring for overnight. The reaction mixture was partitioned between EtOAc and water. The layers were separated and the aqueous layer was further extracted with EtOAc $(2 \times 100 \mathrm{~mL})$. The combined EtOAc layer was washed with saturated $\mathrm{NaCl}$, collected, dried over $\mathrm{Na}_{2} \mathrm{SO}_{4}$, filtered and evaporated to dryness. The yellow oil was subjected to silica gel chromatography using EtOAc: hexane with $0.2 \%$ TEA to remove excess $\mathrm{Boc}_{2} \mathrm{GlyOMe}$ and other impurities. The product was further purified by $16 \%$ EtOAc:0.2\% TEA in toluene to yield $1.371 \mathrm{~g}(1.78 \mathrm{mmol}, 43 \%)$ of the glycine adduct 12 as a mixture of two diastereomers. ${ }^{1} \mathrm{H}$ NMR $\left(300 \mathrm{MHz}, \mathrm{CDCl}_{3}\right.$ ) (as a mixture of 2 diastereomers) $\delta 1.40-1.61\left(\mathrm{~m}, 18 \mathrm{H}, \mathrm{Boc}-\mathrm{CH}_{3}\right), 3.24-3.27\left(\mathrm{~m}, 3 \mathrm{H}, \mathrm{NCH}_{3}\right), 3.65-3.77(\mathrm{~m}, 3 \mathrm{H}$, $\mathrm{COOCH}_{3}$ ), 4.00-4.20 (m, 1H, H-6'), 4.65-4.75 (m, H-5'), 5.05-5.50 (m, 2H, H-4' and 5'-OH), 5.87 $(\mathrm{d}, J=8.2 \mathrm{~Hz})$ and $5.94(\mathrm{~d}, 1 \mathrm{H}, J=8.2 \mathrm{~Hz}),(1 \mathrm{H}, \mathrm{H}-5), 5.97-6.20(\mathrm{~m}, 2 \mathrm{H}, \mathrm{H}-2$ ' and H-3'), 6.50 (d, $J=5.4 \mathrm{~Hz})$ and $6.57(\mathrm{~d}, J=7.6 \mathrm{~Hz})\left(1 \mathrm{H}, \mathrm{H}-1^{\prime}\right), 7.34-7.46(\mathrm{~m}, 4 \mathrm{H}, \mathrm{Bz}), 7.49-7.61(\mathrm{~m}, 2 \mathrm{H}, \mathrm{Bz})$, 7.89-8.03 (m, 4H, Bz), $8.40(\mathrm{~d}, J=8.2 \mathrm{~Hz})$ and $8.46(\mathrm{~d}, J=8.2 \mathrm{~Hz})(1 \mathrm{H}, \mathrm{H}-6) ;{ }^{13} \mathrm{C}$ NMR $(75 \mathrm{MHz}$, $\left.\mathrm{CDCl}_{3}\right) \delta 27.5,28.0,44.7,47.3,52.9,53.2,55.5,57.4,60.0,72.4,72.8,73.7,74.3,78.5,80.7$, 84.1, 84.2, 102.7, 103.1, 128.1, 128.2, 128.4, 128.46, 128.49, 128,57, 128.62, 129.88, 129.9, 130.0, 133.5, 133.6, 133.9, 151.6, 151.8, 151.9, 155.1, 162.5, 162.6, 164.9, 165.2, 165.3, 169.6, 170.1; HRMS for $\mathrm{C}_{37} \mathrm{H}_{43} \mathrm{~N}_{3} \mathrm{O}_{13} \mathrm{SNa}[\mathrm{M}+\mathrm{Na}]^{+}$calcd: 792.2409 found 792.2430 . 
6.11. (2R,3S)-2-amino-3-((2R,3R,4R,5R)-3,4-dihydroxy-5-(3-methyl-2,4-dioxo-3,4dihydropyrimidin-1(2H)-yl)tetrahydrothiophen-2-yl)-3-hydroxypropanoic acid and its $(2 S, 3 R)$ diastereoisomer (13)

To an ice-cooled solution of the elongated product $12(1.22 \mathrm{~g}, 1.6 \mathrm{mmol})$ in 1,4-dioxane (2o mL) was slowly added $1 \mathrm{M} \mathrm{NaOH}(9.6 \mathrm{~mL}, 9.6 \mathrm{mmol}, 6$ eq.). After $10 \mathrm{~min}$, ice bath was removed and the reaction mixture was stirred at room temperature. After completion of the reaction, it was quenched at $0{ }^{\circ} \mathrm{C}$ by addition of TFA $(10 \mathrm{~mL}, \mathrm{pH}=2)$. Next, the reaction mixture was stirred at room temperature for $1 \mathrm{~h}$. After completion of the reaction, the solvent was evaporated to dryness and the crude product was purified by column chromatography using methanol: DCM with $1 \%$ acetic acid to yield $436 \mathrm{mg}$ (79\%) of the deprotected product 13 . ${ }^{1} \mathrm{H}$ NMR (600 MHz, $\mathrm{D}_{2} \mathrm{O}$ ) (as a mixture of 2 diastereomers) $\delta 3.28,3.34\left(2 \mathrm{~s}, \mathrm{~N}-\mathrm{CH}_{3}\right), 3.80-4.10(\mathrm{~m}, 2 \mathrm{H}, \mathrm{H}-4$ ' and $\mathrm{H}-$ 6'), 4.37-4.53 (m, 3H, H-2', H-3' and H-5'), 5.91-5.99 (m, 2H, H-1' and H-5), 8.43 (2d, 1H, $J=$ 6.6 Hz and 6.0 Hz, H-6); ${ }^{13} \mathrm{C}$ NMR (125 MHz, $\left.\mathrm{D}_{2} \mathrm{O}\right) \delta$ 29.3, $29.4\left(\mathrm{NCH}_{3}\right), 52.6,53.7$ (C-4'), 59.1, 59.5 (C-6'), 65.4, 67.7 (C-1'), 69.0, 69.4 (C-5'), 76.0, 76,5 (C-3'), 81.1, 82.2 (C-2'), 102.0, 102, 8 (C-5), 143.1, 143.5 (C-6), 154.2, 154.3 (C-4), 166.8, 166.9 (C-2), 172.5, 173.5 (COOH); HRMS for $\mathrm{C}_{12} \mathrm{H}_{16} \mathrm{~N}_{3} \mathrm{O}_{7} \mathrm{~S}$ [M-H] $]^{-}$calcd: 346.0714 found 346.0696.

6.12. Synthesis of the seryl-analogue 14: (2R,3S)-2-((S)-2-amino-3-hydroxypropanamido)-3$((2 R, 3 R, 4 R, 5 R)-3,4-$ dihydroxy-5-(3-methyl-2,4-dioxo-3,4-dihydropyrimidin-1 $(2 H)$ -

yl)tetrahydrothiophen-2-yl)-3-hydroxypropanoic acid (14a)

HBTU (246 mg, $0.65 \mathrm{mmol}$ ) was added to a solution of Boc-Ser(OTBDMS)-OH (208 mg, $0.65 \mathrm{mmol})$ in THF $(2 \mathrm{~mL})$. The reaction mixture was stirred at room temperature for $1 \mathrm{~h}$. The HOBt activated ester was used as such in the next step. In a separate vessel, unprotected nucleoside $13(92 \mathrm{mg}, 0.26 \mathrm{mmol})$ and $\mathrm{NaHCO}_{3}$ were dissolved in a mixture of THF and water $(1: 1 \mathrm{v} / \mathrm{v}, 2 \mathrm{~mL})$ at room temperature. The active ester from above reaction was added slowly to the reaction mixture and stirring was continued for overnight. Next, the solvent was evaporated to dryness and the crude product was purified by silica gel column chromatography to yield $200 \mathrm{mg}$ semi-pure product. HRMS for $\mathrm{C}_{20} \mathrm{H}_{30} \mathrm{~N}_{4} \mathrm{O}_{11} \mathrm{SNa}$ [M-TBDMS+Na] ${ }^{+}$calcd: 557.1524 found 557.1520.

To a suspension of semi-pure coupled product $(200 \mathrm{mg})$ in water $(1 \mathrm{~mL})$ was added TFA $(1 \mathrm{~mL})$. The reaction mixture was stirred at room temperature for $1 \mathrm{~h}$. After completion of reaction, the solvent was evaporated to dryness. Traces of TFA were removed by co-evaporation with 
toluene. The product was further purified by RP-HPLC using C-18 column to yield $20.7 \mathrm{mg}$ (18\% over three steps, $0.05 \mathrm{mmol}$ ) of product. HRMS for $\mathrm{C}_{15} \mathrm{H}_{21} \mathrm{~N}_{4} \mathrm{O}_{9} \mathrm{~S}[\mathrm{M}-\mathrm{H}]^{-}$calcd: 433.1034 found 433.1032. The obtained diastereomers were separated by using Adamas C18-X-bond $5 \mu \mathrm{m}(250 \times$ $10 \mathrm{~mm}$ ) column using $50 \mathrm{mM}$ TBAF in acetonitrile and water to yield $1.8 \mathrm{mg}$ of the desired isomer (14a) and $5.5 \mathrm{mg}$ of undesired isomer (14b) (with opposite configuration at C-5' and C-6').

Analysis of 14a (the more polar diastereomer): ${ }^{1} \mathrm{H}$ NMR (600 MHz, $\left.\mathrm{D}_{2} \mathrm{O}\right) \delta 1.27$ (t, 4H, $J=7.2$ $\mathrm{Hz}, \mathrm{TEA}-\mathrm{CH}_{3}$ ), 3.19 (q, 2.5H, J = 7.2 Hz, TEA-CH2), 3.28 (s, 3H, N-CH3), 3.74-3.76 (m, 1H, H4'), 3.85-3.90 (m, $2 \mathrm{H}$, Ser- $\left.\beta-\mathrm{CH}_{2}\right), 3.92-3.94(\mathrm{~m}, 1 \mathrm{H}$, Ser- $\alpha-\mathrm{CH}), 4.35-4.41$ (m, $2 \mathrm{H}, \mathrm{H}-3$ ' and H2'), 4.44-4.50 (m, 2H, H-5' and H-6'), 5.92 (d, 1H, $J=5.4 \mathrm{~Hz}, \mathrm{H}-1$ '), 5.96 (d, 1H, $J=8.4 \mathrm{~Hz}, \mathrm{H}-$ 5), 8.47 (d, $1 \mathrm{H}, J=7.2 \mathrm{~Hz}, \mathrm{H}-6) ;{ }^{13} \mathrm{C} \mathrm{NMR}\left(150 \mathrm{MHz}, \mathrm{D}_{2} \mathrm{O}\right) \delta 9.6\left(\mathrm{TEA}-\mathrm{CH}_{3}\right), 29.4\left(\mathrm{~N}_{-} \mathrm{CH}_{3}\right), 48.0$ (TEA-CH 2 ), 52.2 (C-4'), 56.5 (Ser- $\alpha-\mathrm{CH}), 58.8$ (C-6'), 60.3 (Ser- $\left.\beta-\mathrm{CH}_{2}\right), 65.4$ (C-1'), 70.5 (C-5'), 76.4 (C-3'), 81.2 (C-2'), 102.7 (C-5), 143.2 (C-6), 154.3 (C-4), 165.6 (C-2), 166.9 (CONH), 176.9 ( $\mathrm{COOH})$; HRMS for $\mathrm{C}_{15} \mathrm{H}_{21} \mathrm{~N}_{4} \mathrm{O}_{9} \mathrm{~S}$ [M-H] $]^{-}$calcd: 433.1034 found 433.1027.

Analysis of 14b (less polar diastereomer): ${ }^{1} \mathrm{H}$ NMR $\left(600 \mathrm{MHz}, \mathrm{D}_{2} \mathrm{O}\right) \delta 1.26(\mathrm{t}, 3 \mathrm{H}, J=12.6 \mathrm{~Hz}$, TEA-CH 3 ), 3.20 (q, $1 \mathrm{H}, \mathrm{J}=12.6 \mathrm{~Hz}, \mathrm{TEA}-\mathrm{CH}_{2}$ ), 3.28 (s, 3H, N-CH3), 3.78-3.80 (m, 1H, H-4'), $4.03\left(\mathrm{~d}, 2 \mathrm{H}, \mathrm{J}=4.2 \mathrm{~Hz}, \operatorname{Ser}-\beta-\mathrm{CH}_{2}\right), 4.21(\mathrm{t}, 1 \mathrm{H}, \mathrm{J}=4.2 \mathrm{~Hz}$, Ser- $\alpha-\mathrm{CH}), 4.34$ (t, $1 \mathrm{H}, J=4.8 \mathrm{~Hz}, \mathrm{H}-$ 3'), 4.40 (t, 1H, J=3.0 Hz, H-2'), 4.45 (d, 1H, J=3.0 Hz, H-6'), 4.65-4.70 (m, 1H, H-5'), 5.88 (d, $1 \mathrm{H}, J=3.0 \mathrm{~Hz}, \mathrm{H}-1$ '), 5.92 (d, $1 \mathrm{H}, J=8.4 \mathrm{~Hz}, \mathrm{H}-5), 8.44$ (d, $1 \mathrm{H}, J=7.8 \mathrm{~Hz}, \mathrm{H}-6) ;{ }^{13} \mathrm{C}$ NMR $(150$ MHz, $\left.\mathrm{D}_{2} \mathrm{O}\right) \delta 8.2\left(\right.$ TEA-CH$\left._{3}\right), 27.9\left(\mathrm{~N}_{-} \mathrm{CH}_{3}\right), 46.6\left(\mathrm{TEA}-\mathrm{CH}_{2}\right), 54.5$ (C-4'), 54.7 (Ser- $\left.\alpha-\mathrm{CH}\right), 58.3$ (C-6'), 60.2 (Ser- $\left.\beta-\mathrm{CH}_{2}\right), 67.8$ (C-1'), 70.5 (C-5'), 75.5 (C-3'), 81.4 (C-2'), 100.2 (C-5), 142.4 (C6), 152.8 (C-4), 165.5 (C-2), $167.9(\mathrm{CONH}), 175.5$ (COOH); HRMS for $\mathrm{C}_{15} \mathrm{H}_{21} \mathrm{~N}_{4} \mathrm{O} 9 \mathrm{~S}[\mathrm{M}-\mathrm{H}]^{-}$ calcd: 433.1034 found 433.1030 .

6.13. Synthesis of the aspartyl-analogue 15: (2R,3S)-2-((S)-2-amino-succinamido)-3$((2 R, 3 R, 4 R, 5 R)-3,4-$ dihydroxy-5-(3-methyl-2,4-dioxo-3,4-dihydropyrimidin-1 $(2 H)$ -

yl)tetrahydrothiophen-2-yl)-3-hydroxypropanoic acid (15a)

To a solution of unprotected thionucleoside (13) $(90 \mathrm{mg}, 0.26 \mathrm{mmol})$ in a mixture of THF $(1 \mathrm{~mL})$ and water $(1 \mathrm{~mL})$ was added $\mathrm{NaHCO}_{3}(87 \mathrm{mg}, 1.04 \mathrm{mmol}, 4$ eq.). After $5 \mathrm{~min}$, a solution of Boc-Asp(OtBu)-OSu (251 mg, $0.65 \mathrm{mmol}, 2.5$ eq.) in THF $(1 \mathrm{~mL})$ was added. The reaction mixture was stirred at room temperature for overnight. After completion of the reaction, the solvent was evaporated to dryness. The crude product was purified by silica gel column using methanol 
and DCM with $1 \%$ acetic acid to yield $50 \mathrm{mg}(31 \%, 0.081 \mathrm{mmol})$ of the product as a mixture of two diastereomers. HRMS for $\mathrm{C}_{25} \mathrm{H}_{37} \mathrm{~N}_{4} \mathrm{O}_{12} \mathrm{~S}$ [M-H] $]^{-}$calcd: 617.2134 found 617.2150.

To a suspension of semi-pure coupled product $(50 \mathrm{mg}, 0.081 \mathrm{mmol})$ in water $(1 \mathrm{~mL})$ was added TFA $(1 \mathrm{~mL})$ and the reaction mixture was stirred at room temperature for $1 \mathrm{~h}$. After completion of reaction, the solvent was evaporated to dryness. Traces of TFA were removed by co-evaporation with toluene $(2 \times 2 \mathrm{~mL})$. The product was purified by RP-HPLC using C-18 column to yield $15.7 \mathrm{mg}(42 \%, 0.03 \mathrm{mmol})$ of the product as a white solid. Two diastereomers were separated by using Adamas C18-X-bond $5 \mu \mathrm{m}$ prep. $(250 \times 10 \mathrm{~mm})$ column using $50 \mathrm{mM}$ TBAF in acetonitrile and water to yield $1.3 \mathrm{mg}$ of the desired isomer (15a) and $2.3 \mathrm{mg}$ of undesired isomer (15b) (with opposite configuration at C-5' and C-6').

Analysis of 15a (more polar diastereomer): ${ }^{1} \mathrm{H}$ NMR $\left(600 \mathrm{MHz}, \mathrm{D}_{2} \mathrm{O}\right) \delta 1.26(\mathrm{t}, 6 \mathrm{H}, J=7.2 \mathrm{~Hz}$, TEA-CH$), 2.74\left(\mathrm{dd}, 1 \mathrm{H}, \mathrm{J}=7.2 \mathrm{~Hz}\right.$ and $\left.17.4 \mathrm{~Hz}, \mathrm{Asp}-\beta-\mathrm{CH}_{2}, \mathrm{Ha}\right), 2.81(\mathrm{dd}, 1 \mathrm{H}, \mathrm{J}=5.8 \mathrm{~Hz}$ and $\left.17.4 \mathrm{~Hz}, \mathrm{Asp}-\beta-\mathrm{CH}_{2}, \mathrm{Hb}\right), 3.19$ (q, 4H, J = 7.2 Hz, TEA-CH 2$), 3.28\left(\mathrm{~s}, \mathrm{~N}-\mathrm{CH}_{3}\right), 3.68$ (dd, 1H, $J=$ 3.6 Hz and 6.6 Hz, H-4'), 4.27 (dd, 1H, J=5.4 Hz and 7.2 Hz, Asp- $\alpha-C H$ ), 4.25-4.39 (m, 2H, H2' and H-3'), 4.43 (d, 1H, J=7.2 Hz, H-6'), 4.46-4.49 (m, 1H, H-5'), 5.94 (d, 1H, J=6.0 Hz, H1'), 5.97 (d, 1H, $J=8.4 \mathrm{~Hz}, \mathrm{H}-5), 8.48$ (d, 1H, $J=7.8 \mathrm{~Hz}, \mathrm{H}-6) ;{ }^{13} \mathrm{C}$ NMR $\left(150 \mathrm{MHz}, \mathrm{D}_{2} \mathrm{O}\right) \delta 9.6$ (TEA-CH3), $29.3\left(\mathrm{NCH}_{3}\right), 38.4\left(\right.$ Asp- $\left.\beta-\mathrm{CH}_{2}\right), 48.0\left(\mathrm{TEA}-\mathrm{CH}_{2}\right), 51.8(\mathrm{C}-4$ '), 52.2 (Asp- $\alpha-\mathrm{CH}), 58.5$ (C-6’), 64.9 (C-1'), 70.3 (C-5’), 76.2 (C-3’), 81.0 (C-2’), 102.8 (C-5), 143.2 (C-6), 154.3 (C-4), 166.9 (C-2), $170.3(\mathrm{CONH}), 177.0,177.2$ (2 x $\mathrm{COOH})$; HRMS for $\mathrm{C}_{16} \mathrm{H}_{22} \mathrm{~N}_{4} \mathrm{O}_{10} \mathrm{~S}[\mathrm{M}-\mathrm{H}]^{-}$calcd: 461.0984 found 461.0991 .

Analysis of $\mathbf{1 5 b}$ (less polar diastereomer): ${ }^{1} \mathrm{H}$ NMR $\left(600 \mathrm{MHz}, \mathrm{D}_{2} \mathrm{O}\right) \delta 1.26(\mathrm{t}, 6 \mathrm{H}, J=7.2 \mathrm{~Hz}$, TEA-CH $\left.{ }_{3}\right), 2.68\left(\mathrm{dd}, 1 \mathrm{H}, \mathrm{J}=9.6 \mathrm{~Hz}\right.$ and $\left.17.4 \mathrm{~Hz}, \mathrm{Asp}-\beta-\mathrm{CH}_{2}, \mathrm{Ha}\right), 2.93$ (dd, 1H, J = 4.8 Hz and $\left.17.4 \mathrm{~Hz}, \mathrm{Asp}-\beta-\mathrm{CH}_{2}, \mathrm{Hb}\right), 3.19$ (q, 4H, J = 7.2 Hz, TEA-CH$), 3.28$ (s, N-CH3), 3.78 (dd, 1H, J = 3.6 Hz and 4.8 Hz, H-4'), 4.30-4.35 (m, 2H, Asp- $\alpha-C H$ and H-3'), 4.41 (t, 1H, J = 7.2 Hz, H-2'), 4.45 (d, 1H, J = 3.6 Hz, H-6'), 4.63 (dd, 1H, J = 3.6 Hz and 3.6 Hz, H-5'), 5.88 (d, 1H, J = 3.6 Hz, H-1'), 5.93 (d, 1H, J = 7.8 Hz, H-5), 8.44 (d, 1H, J = $7.8 \mathrm{~Hz}, \mathrm{H}-6) ;{ }^{13} \mathrm{C}$ NMR $\left(150 \mathrm{MHz}, \mathrm{D}_{2} \mathrm{O}\right) \delta$ 9.6 (TEA-CH 3$), 29.3\left(\mathrm{NCH}_{3}\right), 38.2\left(\mathrm{Asp}-\beta-\mathrm{CH}_{2}\right), 48.0\left(\mathrm{TEA}-\mathrm{CH}_{2}\right), 52.34(\mathrm{C}-4$ '), $55.6(\mathrm{Asp}-\alpha-\mathrm{CH})$, 59.8 (C-6'), 68.9 (C-1'), 71.8 (C-5'), 76.8 (C-3'), 82.7 (C-2'), 101.7 (C-5), 143.7 (C-6), 154.2 (C4), 167.0 (C-2), $170.6(\mathrm{CONH}), 176.8,177.6$ (2 x COOH); HRMS for $\mathrm{C}_{16} \mathrm{H}_{22} \mathrm{~N}_{4} \mathrm{O}_{10} \mathrm{~S}$ [M-H] ${ }^{-}$calcd: 461.0984 found 461.0975 . 
6.14. Synthesis of the isoleucyl-analogue 16: 2-((2S,3S)-2-amino-3-methylpentanamido)-3((2R,3R,4R, 5R)-3,4-dihydroxy-5-(3-methyl-2,4-dioxo-3,4-dihydropyrimidin-1(2H)-

$y l$ )tetrahydrothiophen-2-yl)-3-hydroxypropanoic acid as a mixture of the (2R,3S)- and (2S,3R)propionic acid derivatives (16a,b)

To a solution of unprotected thionucleoside $(13)(40 \mathrm{mg}, 0.12 \mathrm{mmol})$ in a mixture of THF $(1 \mathrm{~mL})$ and water $(2 \mathrm{~mL})$ was added $\mathrm{NaHCO}_{3}(30 \mathrm{mg}, 0.36 \mathrm{mmol}, 3$ eq.). After $5 \mathrm{~min}$, a solution of Boc-Ile-OSu (92 mg, $0.28 \mathrm{mmol}, 2.4$ eq.) in THF (1 mL) was added. The reaction mixture was stirred at room temperature for $24 \mathrm{~h}$. After completion of the reaction, the solvent was evaporated to dryness. The crude product was purified by silica gel column to yield $48 \mathrm{mg}$ of the product as a white solid. HRMS for $\mathrm{C}_{23} \mathrm{H}_{35} \mathrm{~N}_{4} \mathrm{O}_{10} \mathrm{~S}$ [M-H] ${ }^{-}$calcd: 559.2079 found 559.2084.

To a suspension of semipure coupled product $(46 \mathrm{mg}, 0.082 \mathrm{mmol})$ in water $(1 \mathrm{~mL})$ was added TFA $(1 \mathrm{~mL})$ and the reaction mixture was stirred at room temperature for $1 \mathrm{~h}$. After completion of reaction, the solvent was evaporated to dryness. Traces of TFA was removed by coevaporation with toluene $(2 \times 2 \mathrm{~mL})$. The product was purified by RP-HPLC using C-18 column to yield $14 \mathrm{mg}(37 \%, 0.03 \mathrm{mmol})$ of the product as a white solid. In contrast to the above congeners, both diastereomers could not be separated using our RP-HPLC conditions.

${ }^{1} \mathrm{H}$ NMR for the mixture of diastereomers $\left(600 \mathrm{MHz}, \mathrm{D}_{2} \mathrm{O}\right) \delta 0.93\left(\mathrm{t}, 6 \mathrm{H}, \mathrm{J}=3.6 \mathrm{~Hz}, 2 \mathrm{xIle}-\delta-\mathrm{CH}_{3}\right)$, $1.01\left(\mathrm{t}, 6 \mathrm{H}, \mathrm{J}=6.6 \mathrm{~Hz}, 2 \mathrm{x}\right.$ Ile- $\left.\gamma-\mathrm{CH}_{3}\right), 1.23-1.30\left(\mathrm{~m}, 8 \mathrm{H}, \mathrm{TEA}-\mathrm{CH}_{3}\right.$ and $\left.2 x I l e-\gamma-\mathrm{CH}_{2}, \mathrm{Ha}\right), 1.45-$ 1.55 (m, 2H, 2xIle- $\left.\gamma-\mathrm{CH}_{2}, \mathrm{Hb}\right), 1.90-2.00$ (m, 2H, 2xIle- $\left.\beta-\mathrm{CH}\right), 3.19$ (q, 4H, TEA-CH 2$), 3.28$ (s, $\left.6 \mathrm{H}, 2 \mathrm{xN}-\mathrm{CH}_{3}\right), 3.69(\mathrm{dd}, 1 \mathrm{H}, \mathrm{J}=2.4 \mathrm{~Hz}$ and $3.6 \mathrm{~Hz}, \mathrm{H}-4$ '), 3.79 (dd, 1H, J = 2.4 Hz and $4.8 \mathrm{~Hz}$, H-4'), $3.82(\mathrm{~d}, 1 \mathrm{H}, \mathrm{J}=5.4 \mathrm{~Hz}$, Ile- $\alpha-\mathrm{CH}), 3.84(\mathrm{~d}, 1 \mathrm{H}, \mathrm{J}=6.0 \mathrm{~Hz}$, Ile- $\alpha-\mathrm{CH}), 4.34$ (t, 1H, J = 4.8 Hz, H-3'), 4.38 (t, 1H, J = 6.6 Hz, H-3'), 4.40-4.42 (m), 4.45-4.51 (m), 4.61 (dd, J = 3.6Hz and 3.6 $\mathrm{Hz})(6 \mathrm{H}, 2 \mathrm{xH}-5$ ', 2xH-2' and 2xH-6'), 5.87-6.00 (2xH-1' and 2xH-5), 8.44 (d, 1H, J = 7.8 Hz, H6) $8.48(\mathrm{~d}, 1 \mathrm{H}, \mathrm{J}=7.8 \mathrm{~Hz}, \mathrm{H}-6) ;{ }^{13} \mathrm{C}$ NMR $\left(150 \mathrm{MHz}, \mathrm{D}_{2} \mathrm{O}\right) \delta 11.8,11.9\left(\mathrm{Ile}-\delta-\mathrm{CH}_{3}\right), 15.75,15.78$ $\left(\mathrm{Ile}-\gamma-\mathrm{CH}_{3}\right), 25.3\left(\mathrm{TEA}-\mathrm{CH}_{3}\right), 29.30,29.36\left(\mathrm{NCH}_{3}\right), 37.85,38.16\left(\mathrm{Ile}-\beta-\mathrm{CH}_{2}\right), 48.03\left(\mathrm{TEA}-\mathrm{CH}_{2}\right)$, 51.9, 55.78 (C-4'), 58.69, 59.3, 59.6, 59.7 (C-6' and Ile- $\alpha-C H), 65.1,70.2$ (C-1'), 69.1, 72.0 (C5'), 76.4, 76.9 (C-3'), 81.0, 82.8 (C-2'), 101.7, 102.8 (C-5), 143.1, 143.8 (C-6), 166.8, 166.9 (C-2, $\mathrm{C}=\mathrm{O}), 171.5,172.3$ (amide $\mathrm{CONH}), 176.7,177.0(\mathrm{COOH})$; $\mathrm{HRMS}$ for $\mathrm{C}_{18} \mathrm{H}_{27} \mathrm{~N}_{4} \mathrm{O}_{8} \mathrm{~S}[\mathrm{M}-\mathrm{H}]^{-}$calcd: 459.1555 found 459.1552 . 


\subsection{Crystallization of Tbg-SerRS and Tt-AspRS complexes}

Cloning, overexpression, purification and crystallization of $T b g$-SerRS and $T t$-AspRS were performed as previously described (ref. class II). Crystals of Tbg-SerRS were soaked with $5 \mathrm{mM}$ compound 14a under cryo-conditions with $2.4 \mathrm{mM}$ sodium malonate, $100 \mathrm{mM}$ Bis-tris propane $\mathrm{pH}$ 7.0 and $20 \%$ glycerol (v/v) for 5 hours [32]. Suitable crystals were frozen in liquid nitrogen followed by collecting data.

To soak the aspartyl containing congener into crystals of $T t$-aspRS $1 \mu \mathrm{L}$ of $4 \mathrm{mM}$ of 16a dissolved in $100 \%$ DMSO was directly added to a $3 \mu \mathrm{L} T t$-aspRS crystal containing solution and incubated for 2 hours. Crystals were caught in cryo-loops and directly flash-frozen in liquid nitrogen.

\subsection{Data collection and structure determination}

All datasets were processed using XDS, pointless, aimless and ccp4 [34-37], within the automated processing pipeline of autoproc [38]. The structures of the $T b g$-serRS and $T t$-aspRS ligand-bound complexes were solved by molecular replacement using the previously deposited structure of Species serRS (PDB code: 6RLV) and $T t$-aspRS holoenzyme structure (PDB code: 1L0W), respectively. Initial models were further refinement using alternating cycles in Buster 2.10.3 [39] and manual model building in Coot [40]. Restraints of Compounds 14a and 16a were generated by Web Globle Server.

\subsection{Inhibition assays with E. coli aaRSs}

Cloning, expression and purification of E. coli aaRSs and purification of tRNA was performed as previously described [30], while the in vitro inhibitory activity determination with these purified E. coli aaRSs was fully disclosed in Manesh et al [31].

\section{Acknowledgements}

The authors thank the Belgian FWO for providing a SB Fellowship of the Research Foundation - Flanders to Steff De Graef, the China Scholarship Council for providing scholarships to Luping Pang and KU Leuven for financial support. Mass spectrometry was made possible by the support of the Hercules Foundation of the Flemish Government [20100225E7]. We further greatly appreciate the support from the beamline scientists at the PROXIMA 1 (Soleil Synchrotron, 
France) and ID30B, ID30A3 (ESRF, France) beamlines in facilitating the collection of X-ray scattering data. We are also indebted to Luc Baudemprez for help with NMR spectra measurement and Jef Rozenski for providing MS analysis. No conflicts of interest are declared.

\section{Funding}

This work was supported by the Research Foundation Flanders [Fonds voor Wetenschappelijk Onderzoek, grants G077814N to S.V.S. and A.V.A., G0A4616N to S.D.W. and A.V.A., 12A3916N to B.G., 1S53516N to S. D. G.], the KU Leuven Research Fund [grant 3M14022 to S.D.W. and A.V.A.] and the Chinese Scholarship Council to L.P.

\section{Supporting information}

SI file providing supplementary ligplot figures highlighting all interactions of the ligands with the surrounding protein residues, in addition to NMR and MS spectra for corroboration of chemical structures. Supporting information_albomycin_Gadakh et al.pdf

S1 Movie. Superposition of ligand 14a and seryl-adenylate. While leaving out the protein structure, the superposed ligands are rotated $360^{\circ}$, which allows viewing in detail the small differences in positioning of the amino acid and the modified heterocyclic base, using the core albomycin scaffold. SerAMP vs 14a-superposition-albomycin-Bharat et al.mpg

\section{References}

[1] Y. Zeng, H. Roy, P.B. Patil, M. Ibba, S. Chen, Characterization of Two Seryl-tRNA Synthetases in Albomycin-Producing Streptomyces sp. Strain ATCC 700974, Antimicrob. Agents Chemother., 53 (2009) 4619-4627.

[2] A. Pramanik, U.H. Stroeher, J. Krejci, A.J. Standish, E. Bohn, J.C. Paton, I.B. Autenrieth, V. Braun, Albomycin is an effective antibiotic, as exemplified with Yersinia enterocolitica and Streptococcus pneumoniae, Int. J. Med. Microbiol., 297 (2007) 459-469.

[3] A. Kulkarni, Y. Zeng, W. Zhou, S. Van Lanen, W. Zhang, S. Chen, A Branch Point of Streptomyces Sulfur Amino Acid Metabolism Controls the Production of Albomycin, Appl. Environ. Microbiol., 82 (2016) 467477.

[4] G.F. Gause, Recent Studies on Albomycin, a New Antibiotic, Br. Med. J., 2 (1955) 1177-1179.

[5] G. Benz, T. Schröder, J. Kurz, C. Wünsche, W. Karl, G. Steffens, J. Pfitzner, D. Schmidt, Constitution of the Deferriform of the Albomycins $\delta 1, \delta 2$ and $\varepsilon$, Angew. Chem. Int. Ed., 21 (1982) 527-528.

[6] G. Benz, Albomycine, I Enzymatische Spaltung der Desferriform der Albomycine $\delta 1$, $\delta 2$, Liebigs Annalen der Chemie, 1984 (1984) 1399-1407. 
[7] G. Benz, L. Born, M. Brieden, R. Grosser, J. Kurz, H. Paulsen, V. Sinnwell, B. Webber, Albomycine, II. Absolute Konfiguration der Desferriform der Albomycine, Liebigs Annalen der Chemie, 1984 (1984) 14081423.

[8] A. Pramanik, V. Braun, Albomycin Uptake via a Ferric Hydroxamate Transport System of Streptococcus pneumoniae R6, J. Bacteriol., 188 (2006) 3878-3886.

[9] A. Hartmann, H.P. Fiedler, V. Braun, Uptake and conversion of the antibiotic albomycin by Escherichia coli K-12, Eur J Biochem, 99 (1979) 517-524.

[10] W.S. Spector, J.N. Porter, G.C. De Mello, Handbook of toxicology, vol. II, 1958.

[11] A.L. Stefanska, M. Fulston, C.S. Houge-Frydrych, J.J. Jones, S.R. Warr, A potent seryl tRNA synthetase inhibitor SB-217452 isolated from a Streptomyces species, The Journal of antibiotics, 53 (2000) 13461353.

[12] Y. Zeng, A. Kulkarni, Z. Yang, P.B. Patil, W. Zhou, X. Chi, S. Van Lanen, S. Chen, Biosynthesis of Albomycin $\delta 2$ Provides a Template for Assembling Siderophore and Aminoacyl-tRNA Synthetase Inhibitor Conjugates, ACS Chem. Biol., 7 (2012) 1565-1575.

[13] H.P. Fiedler, F. Walz, A. Döhle, H. Zähner, Albomycin: Studies on fermentation, isolation and quantitative determination, Appl. Microbiol. Biotechnol., 21 (1985) 341-347.

[14] M.W. Bredenkamp, C.W. Holzapfel, A.D. Swanepoel, Synthesis of the thionucleoside moiety of albomycin? 1, S. Afr. J. Chem., 44 (1991) 31-33.

[15] Z. Lin, X. Xu, S. Zhao, X. Yang, J. Guo, Q. Zhang, C. Jing, S. Chen, Y. He, Total synthesis and antimicrobial evaluation of natural albomycins against clinical pathogens, Nature Communications, 9 (2018) 3445.

[16] Y.-M. Lin, M.J. Miller, Practical Synthesis of Hydroxamate-Derived Siderophore Components by an Indirect Oxidation Method and Syntheses of a DIG-Siderophore Conjugate and a Biotin-Siderophore Conjugate, J. Org. Chem., 64 (1999) 7451-7458.

[17] H. Paulsen, M. Brieden, G. Benz, Verzweigte und kettenverlängerte Zucker, XXXI. Synthese des Sauerstoffanalogons der Desferriform von $\delta 1$-Albomycin, Liebigs Annalen der Chemie, 1987 (1987) 565575.

[18] G.H. Vondenhoff, B. Gadakh, K. Severinov, A. Van Aerschot, Microcin C and Albomycin Analogues with Aryl-tetrazole Substituents as Nucleobase Isosters Are Selective Inhibitors of Bacterial Aminoacyl tRNA Synthetases but Lack Efficient Uptake, ChemBioChem, 13 (2012) 1959-1969.

[19] L.L. Chen, X. Ming, J.D. Cen, Improved and Practical Synthesis of 2-Deoxy-L-ribose by Hypophosphite-Mediated Deoxygenation, Synth. Commun., 42 (2012) 1-7.

[20] T.K.M. Shing, Y.C. Leung, K.W. Yeung, Catalytic asymmetric epoxidation of alkenes with arabinosederived uloses, Tetrahedron, 59 (2003) 2159-2168.

[21] Y. Tsuda, M. Nishimura, T. Kobayashi, Y. Sato, K. Kanemitsu, Regioselective Monotosylation of Nonprotected and Partially Protected Glycosides by the Dibutyltin Oxide Method, Chem. Pharm. Bull., 39 (1991) 2883-2887.

[22] Q.Q. He, N. Wimmer, G. Verquin, W. Meutermans, V. Ferro, Investigations into the decomposition of aminoacyl-substituted monosaccharide scaffolds from a drug discovery library, Org. Biomol. Chem., 13 (2015) 4070-4079.

[23] B. Muller, M. Blaukopf, A. Hofinger, A. Zamyatina, H. Brade, P. Kosma, Efficient Synthesis of 4Amino-4-deoxy-L-arabinose and Spacer-Equipped 4-Amino-4-deoxy-L-arabinopyranosides by Transglycosylation Reactions, Synthesis, (2010) 3143-3151.

[24] A. Zamyatina, R. Hollaus, M. Blaukopf, P. Kosma, Synthesis of lipid A and inner-core lipopolysaccharide (LPS) ligands containing 4-amino-4-deoxy-L-arabinose units, Pure Appl. Chem., 84 (2012) 11-21.

[25] E.J. Reist, D.E. Gueffroy, L. Goodman, Synthesis of 4-Thio-L-ribofuranose and the Corresponding Adenine Nucleosides, J. Am. Chem. Soc., 86 (1964) 5658-5663. 
[26] N.A. Al-Masoudi, Y.A. Al-Soud, A.I. Khodair, Some 2 '-modified 4 '-thionucleosides via sulfur participation and synthesis of thio-AZT from 4 '-thiofuiranoid 1,2-glycal, Phosphorus Sulfur Silicon Relat. Elem., 178 (2003) 1199-1209.

[27] V. Pejanovic, Z. Stokic, B. Stojanovic, V. Piperski, M. Popsavin, V. Popsavin, Synthesis and biological evaluation of some novel 4 '-thio-L-ribonucleosides with modified nucleobase moieties, Bioorg. Med. Chem. Lett., 13 (2003) 1849-1852.

[28] H.D. Flosadottir, H. Jonsson, S.T. Sigurdsson, O. Ingolfsson, Experimental and theoretical study of the metastable decay of negatively charged nucleosides in the gas phase, Phys. Chem. Chem. Phys., 13 (2011) 15283-15290.

[29] G.S. Ti, B.L. Gaffney, R.A. Jones, Transient protection: efficient one-flask syntheses of protected deoxynucleosides, Journal of the American Chemical Society, 104 (1982) 1316-1319.

[30] B. Zhang, S. De Graef, M. Nautiyal, L. Pang, B. Gadakh, M. Froeyen, L. Van Mellaert, S.V. Strelkov, S.D. Weeks, A. Van Aerschot, Family-wide analysis of aminoacyl-sulfamoyl-3-deazaadenosine analogues as inhibitors of aminoacyl-tRNA synthetases, European Journal of Medicinal Chemistry, 148 (2018) 384396.

[31] M. Nautiyal, S. De Graef, L. Pang, B. Gadakh, S.V. Strelkov, S.D. Weeks, A. Van Aerschot, Comparative analysis of pyrimidine substituted aminoacyl-sulfamoyl nucleosides as potential inhibitors targeting class I aminoacyl-tRNA synthetases, Eur J Med Chem, 173 (2019) 154-166.

[32] L. Pang, M. Nautiyal, S. De Graef, B. Gadakh, V. Zorzini, A. Economou, S.V. Strelkov, A. Van Aerschot, S.D. Weeks, Structural insights into the binding of natural pyrimidine-based inhibitors of class II aminoacyl-tRNA synthetases, ACS Chem. Biol., (2020) Submitted.

[33] A. Poterszman, M. Delarue, J.C. Thierry, D. Moras, Synthesis and recognition of aspartyl-adenylate by Thermus thermophilus aspartyl-tRNA synthetase, J Mol Biol, 244 (1994) 158-167.

[34] W. Kabsch, Xds, Acta Crystallogr D Biol Crystallogr, 66 (2010) 125-132.

[35] P. Evans, Scaling and assessment of data quality, Acta Crystallogr D Biol Crystallogr, 62 (2006) 72-82.

[36] P.R. Evans, G.N. Murshudov, How good are my data and what is the resolution?, Acta Crystallogr D

Biol Crystallogr, 69 (2013) 1204-1214.

[37] M.D. Winn, C.C. Ballard, K.D. Cowtan, E.J. Dodson, P. Emsley, P.R. Evans, R.M. Keegan, E.B. Krissinel, A.G. Leslie, A. McCoy, S.J. McNicholas, G.N. Murshudov, N.S. Pannu, E.A. Potterton, H.R. Powell, R.J. Read, A. Vagin, K.S. Wilson, Overview of the CCP4 suite and current developments, Acta Crystallogr D Biol Crystallogr, 67 (2011) 235-242.

[38] C. Vonrhein, C. Flensburg, P. Keller, A. Sharff, O. Smart, W. Paciorek, T. Womack, G. Bricogne, Data processing and analysis with the autoPROC toolbox, Acta Crystallogr D Biol Crystallogr, 67 (2011) 293302.

[39] G. Bricogne, E. Blanc, M. Brandl, C. Flensburg, P. Keller, W. Paciorek, P. Roversi, A. Sharff, O.S. Smart, C. Vonrhein, T.O. Womack, BUSTER, Global Phasing Ltd., Cambridge, United Kingdom, 2017.

[40] P. Emsley, B. Lohkamp, W.G. Scott, K. Cowtan, Features and development of Coot, Acta Crystallogr D Biol Crystallogr, 66 (2010) 486-501. 